\title{
3. SITE 304: JAPANESE MAGNETIC LINEATIONS
}

\author{
The Shipboard Scientific Party ${ }^{1}$
}

\section{SITE DATA}

Date Occupied: 24 August 1973 (1746)

Date Departed: 27 August 1973 (1810)

Time on Site: 72.4 hours

Position: $39^{\circ} 20.27^{\prime} \mathrm{N}, 155^{\circ} 04.19^{\prime} \mathrm{E}$

Water Depth: 5630 corrected meters (echo sounding)

Bottom Felt With Drill Pipe At: 5640 meters below rig floor Penetration: 347 meters

Number of Holes: 1

Number of Cores: 17

Total Length of Cored Section: 131.0 meters

Total Core Recovered: 30.1 meters

\section{BACKGROUND AND OBJECTIVES}

The background information for Site 304 is nearly identical to Site 303. This site (Figure 1) lies in the southern portion of the Japanese lineation pattern on magnetic anomaly M-9 (Figure 2). This pattern extends south from Site 304 through M-10, and perhaps as far as $\mathrm{M}-11, \mathrm{M}-12$, and $\mathrm{M}-13$, but the ccrrelation of these latter anomalies is more uncertain, and their supposed lineation direction is $10^{\circ}$ more easterly than the lineations to the north.

It is hoped that the basement age at Site 304 will further confirm the correlation of the Japanese and Phoenix magnetic lineations. Besides this general correlation, it is also hoped that Site 304 can be compared to Site 303 to determine a gradient in the basement age of the Japanese lineations. Sites 303 and 304 on the Japanese lineations and Site 166 on the Phoenix lineations can all be used to recalibrate the upper half of the Larson and Pitman time scale for this reversal sequence. The age predicted by Larson and Pitman (1972) for Site 304 is early Hauterivian.

Besides the basement age and age gradient, the sediments recovered at Site 304 should shed light on reflection profiling information between this area and Shatsky Rise, $900 \mathrm{~km}$ to the south. Reflection profiling

'Roger L. Larson, Lamont-Doherty Geological Observatory, Palisades, New York (Co-chief scientist); Ralph Moberly, Hawaii Institute of Geophysics, Honolulu, Hawaii (Co-chief scientist); David Bukry, U.S. Geological Survey, La Jolla, California; Helen P. Foreman, Oberlin College, Oberlin, Ohio; James V. Gardner, Scripps Institution of Oceanography, La Jolla, California; John B. Keene, Scripps Institution of Oceanography, La Jolla, California; Yves Lancelot, Lamont-Doherty Geological Observatory, Palisades, New York; Hanspeter Luterbacher, Esso Production Research-European, Begles, France; Monte C. Marshall, U.S. Geological Survey, Menlo Park, California; Albert Matter, Universitat Bern, Bern, Switzerland.

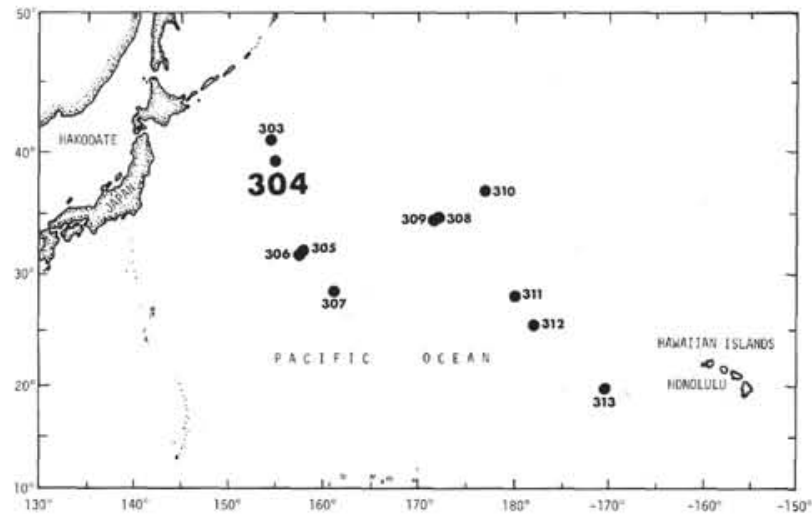

on the Antipode-3 expedition revealed a lower transparent layer in the area that lies between an upper transparent and upper opaque layer above, and a lower opaque layer (basement?) below. This lower transparent layer reaches a maximum thickness on the flank of Shatsky Rise and wedges out nearly completely at the latitude of Site 303. It is probably composed of sediment deposited at a high rate and may be related to the equatorial passage of this portion of the Pacific plate during its early history.

\section{OPERATIONS}

As with Site 303 , we held our survey time to a minimum by steaming directly along the Conrad-1405 track that was our reference profile (Figure 2). This crossed the Japanese magnetic lineations nearly across

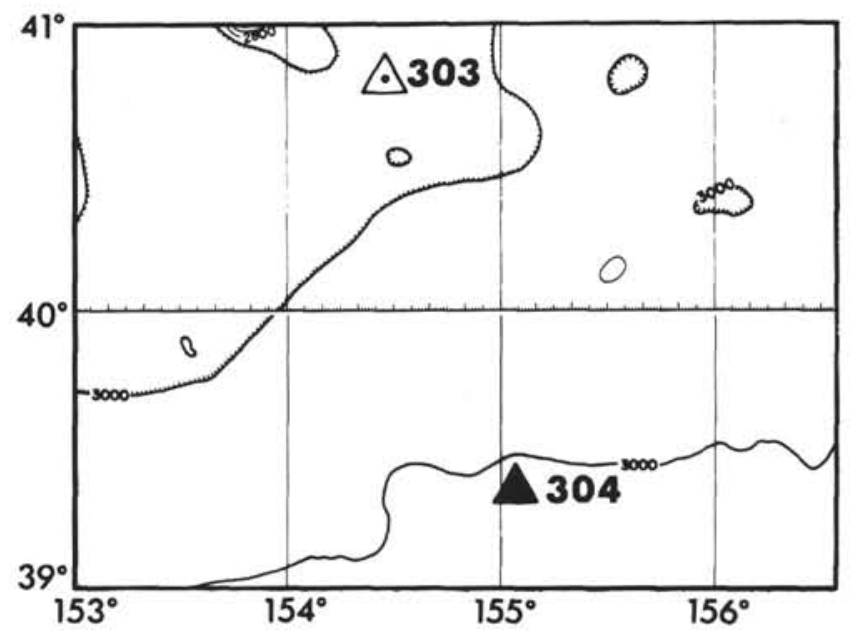

Figure 1. Bathymetry in the region of Site 304 (after Chase et al., 1971). Contour interval $200 \mathrm{fm}$ uncorrected. 


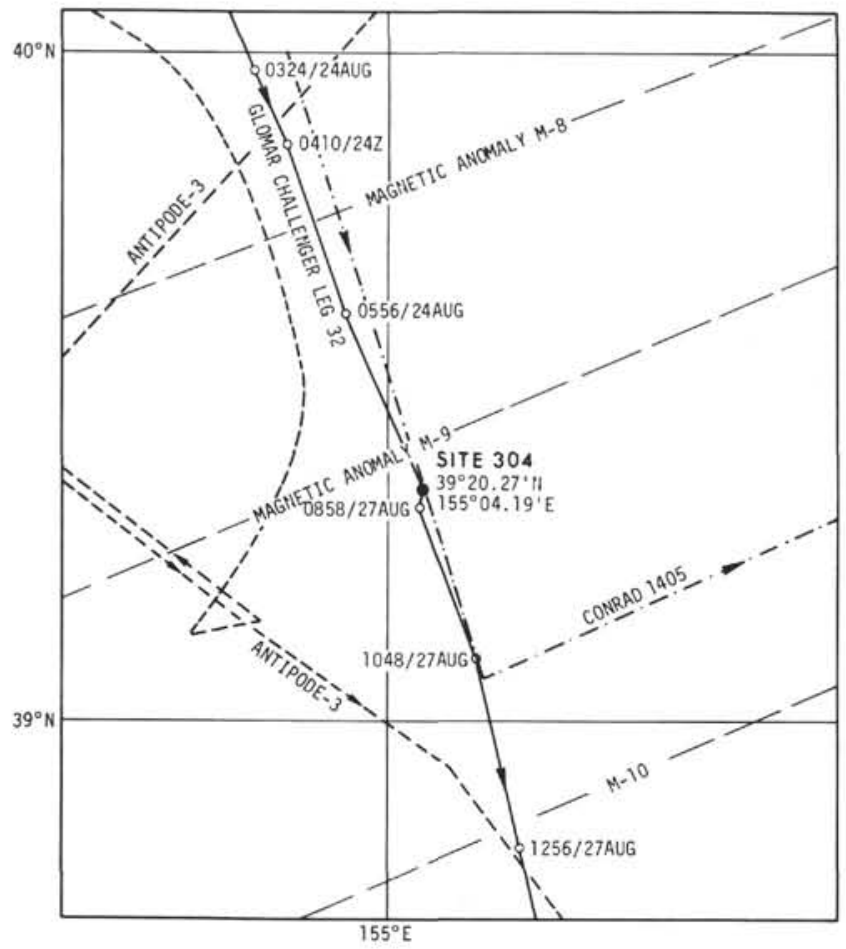

Figure 2. Track chart in the vicinity of Site 304. Solid track is Leg 32 Glomar Challenger, dash-dot track is Conrad-1405, dashed track is Antipode-3, and long dashed lines are identified magnetic anomalies. Navigation points marked as open circles and annotated timel day-month.

strike, so we could follow our position on the lineation pattern and on the Conrad-1405 profile nearly exactly. Our seismic profile (Figure 3) and the Conrad profile were nearly identical. We dropped a presoaked beacon at $1745 \mathrm{hr}$ (local) on 24 August 1973 in a water depth of
5624 meters (corrected to the hydrophone from 2988 fathoms on the PDR).

A seismic record from a sonobuoy was run on station to determine the depth to the first hard reflector and to confirm that no shallow reflectors would make it difficult to spud in the bottom hole assembly.

As with Site 303, we left the site by steaming slowly to the north while streaming the gear, turning, and coming back across the beacon enroute to Shatsky Rise.

Our experience at Site 303 and the similar appearance of the seismic records gave us confidence that the upper 200 meters at Site 304 would be Holocene to Miocene soft ooze which would provide a good material for spudding in, but was of secondary scientific importance. Thus, we spudded in without a mudline core and took the first core at 105 meters. This confirmed our notions of the upper portion of the section, so we washed down to 216 meters where we cored nearly continuously to basement at 335 meters (total depth $=347 \mathrm{~m}$ ). Cores 2 and 3 recovered a large amount of pelagic clay, but very little other than chert was recovered from Cores 4 through 13. On Core 12 we tried to improve recovery with a "pack-off" system that consisted of two O-rings near the base of the inner core barrel to prevent circulation water from leaking between the core barrel and the bit and jetting out directly at the mouth of the core barrel. While this increased the ratio of pump pressure to pumping rate, only chert and a very little nannofossil ooze were recovered. On Core 12 we also ran a plastic sock at the core catcher that was torn off by the chert and may have jammed the check valve at the top of the core barrel.

On Core 13 we removed the sock but left the O-rings in place and attempted to core the hole with intervals of no circulation alternating with minimum circulation. After we cored 4 meters, the bit circulation became partially blocked with chert chips from the "dry drilling" and again we recovered practically nothing.
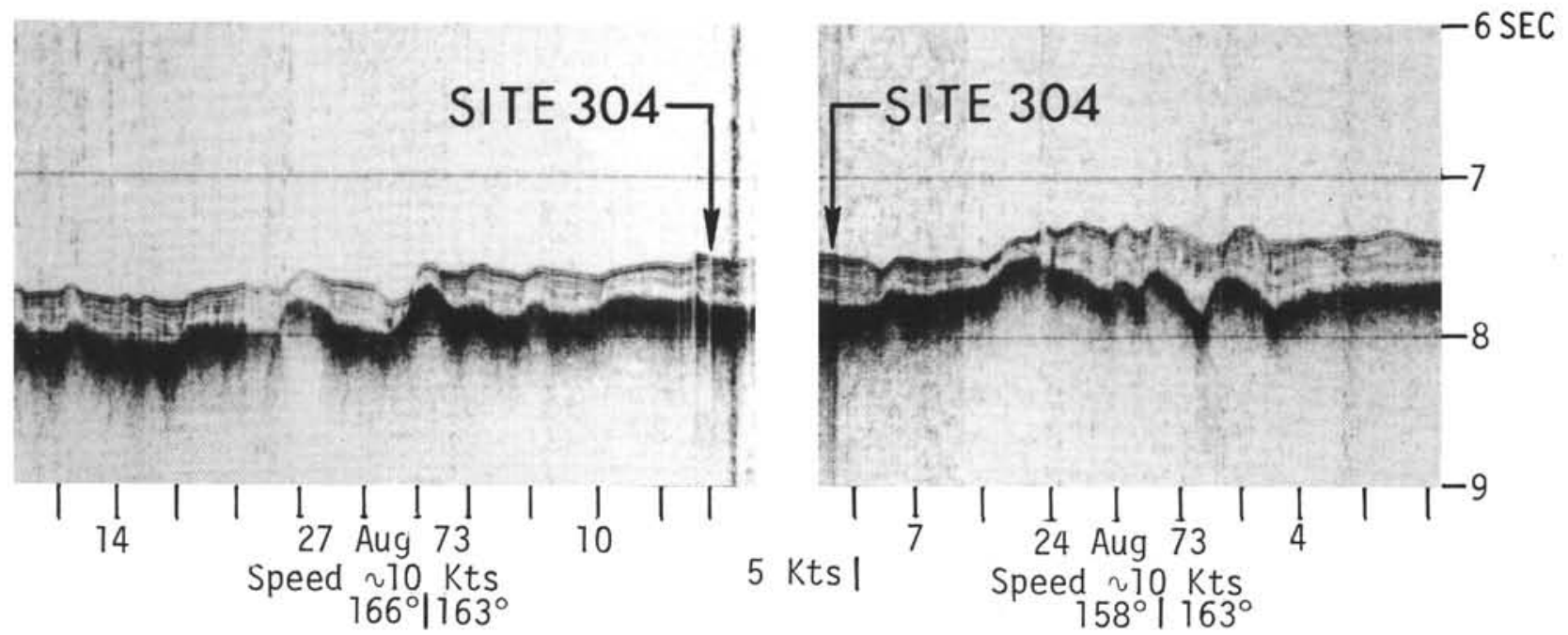

Figure 3. Seismic profiler section approaching and leaving Site 304. 
On Core 14 we replaced the sock, left the O-rings in place on the core barrel, and attempted to dry drill the entire core with very little rotation. We penetrated 3.5 meters and recovered at least 1.5 meters of soupy nannofossil ooze and chert that proved to be Hauterivian to Valanginian. The next core recovered basalt.

After two partial cores (15 and 16) in basalt that penetrated 8.5 meters and recovered 7.6 meters of the basement, we attempted an oriented core with the Sperry-Sun orienting device. Four meters were penetrated and the core barrel was retrieved only to find that the joint at the core catcher had unscrewed, leaving the shoe, core catcher, core liner, and core in the bottom of the drill string. Other than orientation, our objectives for Site 304 had been met and we abandoned the hole.

When the bit was recovered we noted it had suffered moderately bad "shirttail" wear, and that two of the four roller cones were locked from bearing failure.

The core orientation failed for at least two reasons: first of all because the unscrewed core catcher containing the scribe could no longer be related to the compass in the upper part of the core barrel. Besides that problem, the compass was erratic, indicating close magnetic field influence. This could have been the latch sleeve that became disconnected from the core barrel and slid down the barrel, allowing the core barrel to be jostled about during coring. This latter phenomenon may have caused the joint to unscrew, but it is also possible that the monel alloy offers less friction than regular steel. Regardless of these problems, a $15-\mathrm{cm}$ piece of basalt was recovered that was well scribed, and the camera system for photographing the compass worked well.

At $1810 \mathrm{hr}$ (LT) on 27 August 1973 we were underway from Site 304 enroute to Shatsky Rise. The intervals drilled and cored at Site 304 are listed in Table 1.

\section{LITHOLOGIC SUMMARY}

The top 105.5 meters of sediment at Site 304 were not sampled and the lithology is unknown. Possibly it is an ashy to radiolarian-diatom ooze similar to the upper part of the section at Site 303 (about $160 \mathrm{~km}$ to the north).

Sediments were recovered from 105.5 to 115 meters (Core 1), the drill string was washed down to 216 meters, and a 9.5-meter core was recovered (Core 2). The section was then continuously cored from 235 to 347 meters, basalt being encountered at 335 meters depth. Recovery was relatively good in the two spot-cored intervals, but quite poor in the continuously cored sections because of interbedded chert layers.

The section can be divided into four units as follows:

Unit 1-Radiolarian-diatom ooze (Core 1).

Unit 2-Unfossiliferous pelagic clay and rad-bearing chert (Cores 2 through 11).

Unit 3-Nanno ooze and chert (Cores 12 through 14).

Unit 4-Basalt (Cores 15 through 17).

\section{Unit 1-Radiolarian-diatom Ooze (Core 1)}

This unit consists predominantly of diatoms and radiolarians with lesser amounts of silicoflagellates. The siliceous microfossils are very well preserved. Clay minerals are essentially absent in the smear slides; X-ray results indicate $94.8 \%$ of a bulk sample from this unit is amorphous. The extent of the unit is not known because of discontinuous coring. Core 2, Section 1 contains a brown clay with sparse radiolarians and some diatom fragments, but probably represents cavings from uphole. This sediment seems to be the transitional lithology between Unit 1 and Unit 2.

TABLE 1

Coring Summary

\begin{tabular}{|c|c|c|c|c|c|c|c|}
\hline Core & $\begin{array}{l}\text { Date } \\
\text { (Aug. } \\
\text { 1973) }\end{array}$ & Time & $\begin{array}{l}\text { Depth From } \\
\text { Drill Floor } \\
\text { (m) }\end{array}$ & $\begin{array}{l}\text { Depth Below } \\
\text { Sea Floor } \\
\text { (m) }\end{array}$ & $\begin{array}{l}\text { Length } \\
\text { Cored } \\
(\mathrm{m})\end{array}$ & $\begin{array}{l}\text { Length } \\
\text { Recovered } \\
\text { (m) }\end{array}$ & $\begin{array}{c}\text { Recovery } \\
(\%)\end{array}$ \\
\hline 1 & 25 & 0945 & $5745.5-5755.0$ & $105.5-115.0$ & 9.5 & 5.5 & 58 \\
\hline 2 & 25 & 1250 & $5856.0-5865.5$ & $216.0-225.5$ & 9.5 & 2.8 & 29 \\
\hline 3 & 25 & 1505 & $5875.0-5884.0$ & $235.0-244.0$ & 9.0 & 9.0 & 100 \\
\hline 4 & 25 & 1700 & $5884.0-5893.0$ & $244.0-253.0$ & 9.0 & $\operatorname{tr}$ & 1 \\
\hline 5 & 25 & 1930 & $5893.0-5902.5$ & $253.0-262.5$ & 9.5 & 0.4 & 4 \\
\hline 6 & 25 & 2145 & $5902.5-5911.5$ & $262.5-271.5$ & 9.0 & $\operatorname{tr}$ & 1 \\
\hline 7 & 26 & 0000 & $5911.5-5921.0$ & $271.5-281.0$ & 9.5 & 0.4 & 4 \\
\hline 8 & 26 & 0220 & $5921.0-5930.0$ & $281.0-290.0$ & 9.0 & 0.9 & 10 \\
\hline 9 & 26 & 0430 & $5930.0-5939.5$ & $290.0-299.5$ & 9.5 & 0.5 & 5 \\
\hline 10 & 26 & 0630 & $5939.5-5948.5$ & $299.5-308.5$ & 9.0 & 0.4 & 4 \\
\hline 11 & 26 & 0830 & $5948.5-5958.0$ & $308.5-318.0$ & 9.5 & 0.3 & 3 \\
\hline 12 & 26 & 1020 & $5958.0-5967.0$ & $318.0-327.0$ & 9.0 & 0.3 & 3 \\
\hline 13 & 26 & 1215 & $5967.0-5971.0$ & $327.0-331.0$ & 4.0 & $\operatorname{tr}$ & 1 \\
\hline 14 & 26 & 1400 & $5971.0-5974.5$ & $331.0-334.5$ & 3.5 & 1.5 & 43 \\
\hline 15 & 26 & 1705 & $5974.5-5977.5$ & $334.5-337.5$ & 3.0 & 2.3 & 77 \\
\hline 16 & 26 & 2235 & $5977.5-5983.0$ & $337.5-343.0$ & 5.5 & 5.3 & 96 \\
\hline 17 & 27 & 1745 & $5983.0-5987.0$ & $343.0-347.0$ & 4.0 & 0.5 & 13 \\
\hline Total & & & & & 131.0 & 30.1 & 23.0 \\
\hline
\end{tabular}




\section{Unit 2-Pelagic Clay and Chert (Cores 2 through 11)}

Unit 2 is an unfossiliferous brown pelagic clay with thin interbeds of pale orange altered volcanic ash (Core 2 , Section 2) grading to a zeolitic pelagic clay in Core 3 , Section 6, which becomes a semilithified clay (Cores 8 and 9). X-ray data show $65.4 \%$ amorphous and $11.4 \%$ montmorillonite, indicating the volcanogenic nature of the sediments. The first chert was recovered from the base of Core 3 and consists of small fragments in brown zeolitic clay. The chert is dusky brown with thin $(<1 \mathrm{~cm})$ moderate brown layers and internal molds of Radiolaria composed of fine-grained chalcedony with coarser sheaves of chalcedony. The very low recovery precludes any determination of the relative amounts of clay and chert. When sediment was recovered with the chert, it was consistently a zeolitic (dominantly clinoptilolite) clay with minor amounts of volcanic glass, fish debris, and hematite.

Brecciation and resilicification is common in the samples recovered in this hole. Vugs lined with quartz crystals and botryoidal chalcedony fillings occur in Core 4. One chert sample from Core 4 was dark yellowishorange and had a less silicified, less vitreous, white layer attached. The boundary between the two lithologies was sharp.

In Cores 5, 7, 8, and 9 brown chert was recovered, and in Cores 8 and 9 the chert was in sharp contact with less silicified moderate brown zeolitic claystone.

Only chert was recovered from Cores 10 and 11 ; consequently, the position of the contact between Units 2 and 3 is not precisely known. Arbitrarily, it is placed between Cores 11 and 12 .

\section{Unit 3-Nanno Ooze and Chert (Cores 12 through 14)}

The drilling difficulties encountered because of the difference in competencies of chert and nanno ooze yielded very poor recovery in this unit.

The nanno ooze is a slightly hematitic coccolith ooze (Core 14). The cherts, colored various shades of brown, are massive to banded, some showing chalcedony-filled veins and lenses (Core 14) and quartz crystals lining vugs (Cores 11 and 15). The relative amounts of chert and nanno ooze in this unit are unknown due to poor recovery.

Because Core 15 contained both chert and extrusive basalt, it is assumed that Unit 3 lies just above the basalt; however, the actual contact was not recovered.

\section{Unit 4-Fine-grained Basalt (Cores 15 through 17)}

This unit consists of fine-grained, nonporphyritic basalt. The contact between the basalt and the overlying sediments was not recovered. No glassy selvages survived the coring but the fine, feathery texture of the topmost basalt suggests that the basalt-sediment interface missed recovery by only a few centimeters. The basalt is not as highly fractured as that found at Site 303, the average fracture spacing here being about $5 \mathrm{~cm}$. The fractures are filled with calcite, celadonite, montmorillonite, pyrite, and sometimes chalcedony. One 2$\mathrm{cm}$-thick calcite vein near the center of the basalt is particularly noteworthy in that it contains pyritized fecal pellets (Favreina). Sparse vesicles $(<1 \mathrm{~mm})$ are filled with calcite, celadonite, or montmorillonite.
Excepting the very fine crystallinity at the top of the basalt, the grain size is fine and fairly uniform throughout the recovered interval. The plagioclase laths are about $80 \times 600 \mu \mathrm{m}$, whereas the pyroxene grains average about $120 \mu \mathrm{m}$ in diameter. The texture of the basalt is generally intergranular to intersertal. At places in the basalt, the texture becomes coarsely feathery, with the pyroxene and plagioclase laths intergrown in bundles or sheaves $(\sim 300 \times 800 \mu \mathrm{m})$. Commonly, the two textures can be seen in the same thin section.

This basalt is more altered than that at Site 303. The pyroxene is much more altered than the plagioclase, and the degree of alteration varies throughout the cored interval. Olive-brown montmorillonite is the typical alteration product.

Modal analysis shows that the percentage of plagioclase $(\sim 35 \%-40 \%)$ remains fairly constant through the interval, whereas the amount of pyroxene varies from about $40 \%$ in relatively unaltered (alteration $\sim 10 \%$ ) basalt to only about $15 \%$ in the more highly altered (alteration $\sim 40 \%$ ) basalt. This basalt has a high content of opaque minerals (10\%-15\%). Preliminary analysis of the plagioclase composition shows that the laths are normally zoned and have an average composition of $\mathrm{An}_{46}$ (calcic andesine).

\section{Conclusions}

The lithologies sampled at Site 304 are essentially identical to the section sampled at Site 303 (Figure 4). Because of the poor recovery and lack of recovered contacts at both sites, the relative differences in unit thicknesses in Figure 4 may be largely artificial. The only lithology found at Site 304, but not recovered at Site 303 , is the unfossiliferous pelagic clay of Core 2, Section 1. A summary of the sediment smear slide data is found in Table 2.

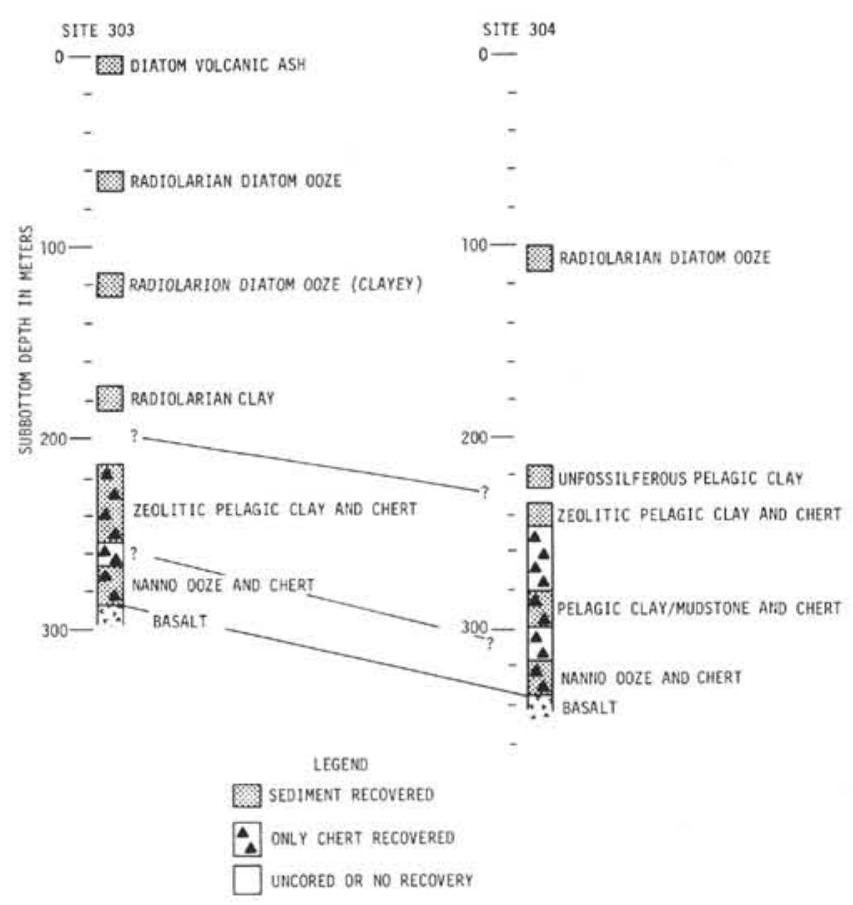

Figure 4. Lithologic correlation between Sites 303 and 304. 
TABLE 2

Smear Slide Summary, Site 304

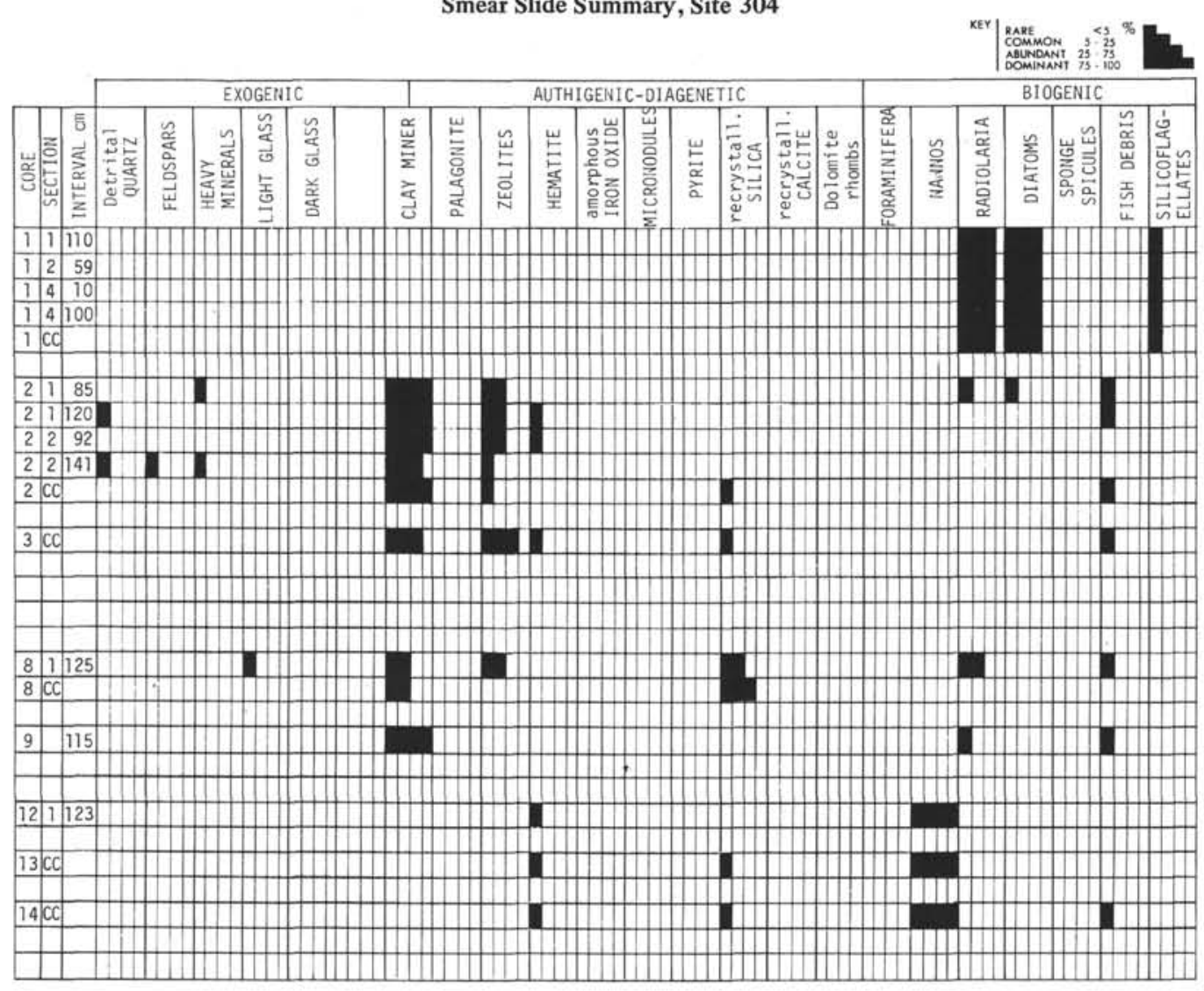

The interpretation of the origin of the lithologies at Site 304 is similar to that for Site 303. The bottommost sediments recovered, the nanno ooze unit (Cores 12-14), represent sediments accumulated just above the carbonate compensation depth (CCD). The nannofossils and sparse foraminifers are moderate- to well-preserved in Site 304 and poorly to moderately preserved at Site 303 , suggesting that the CCD may have been deeper at the time the basal sediments at Site 304 accumulated than at the time the basal sediments at Site 303 were deposited. The thickness of the Cretaceous section is not as large as would be expected from a high productivity zone such as the equator. These sediments were most likely deposited toward the outer edge of the equatorial high productivity area, yet above the CCD.

An unrecovered unconformity (also inferred from Site 303) probably exists between the Upper Cretaceous and the Miocene as suggested by the sedimentation rates. The time represented. by the hiatus was the time that sedimentation shifted from above to below the CCD.

The clays and partially crystallized cherts of Unit 2 represent a dissolution facies deposited on the outer margin of a high productivity zone below the CCD. The radiolarian-diatom ooze of Unit 1 is simply the uncrystallized equivalent of Unit 2 . The moderate average accumulation rates for these two units $(16 \mathrm{~m} / \mathrm{m} . \mathrm{y}$.) suggest they are not abyssal clay facies, which typically have rates an order of magnitude less than this.

If this site were situated south of the equator during the Valanginian to Hauterivian, its passage beneath the equatorial high productivity zone corresponded to a time when its surface was at or below the CCD. Thus, either the plate subsided rapidly away from the ridge or the CCD was relatively higher than it is today.

Unlike at Site 303, the basalt recovered at Site 304 has no noticeable alteration of grain size and color indicative of multiple flow units. Because of their intimate intermingling, the variation from intergranular to coarsely feathery textures appears to be due to chemical differences, probably volatile content, in the melt and not differences in cooling rate. Twelve meters of basalt were cored and only 9.8 meters were recovered. This missing material could have contained additional flow margins. However, Cores 15 and 16 are missing only about 30 and $20 \mathrm{~cm}$, respectively. It seems unlikely that these small intervals could have contained flow margins and yet there are noticeable grain size differences in the adjacent, recovered basalt. Thus it appears that at least the upper 8 meters of the basalt represent a single cooling unit. A unit this thick is probably either a ponded lava flow or a sill. While not conclusive, the very fine grain size of the basalt throughout the interval argues in favor of the basalt having cooled rapidly and therefore being extrusive.

\section{GEOCHEMICAL MEASUREMENTS}

Alkalinity, $p \mathrm{H}$, and salinity measurements for Site 304 are summarized in Table 3 and presented graphically in Figure 5. The sediments were squeezed at $4^{\circ} \mathrm{C}$ to obtain the interstitial water. Three interstitial water samples were collected. 
TABLE 3

Summary of Shipboard Geochemical Data

\begin{tabular}{lcccccc}
\hline $\begin{array}{l}\text { Sample } \\
\text { (Interval } \\
\text { in cm) }\end{array}$ & $\begin{array}{c}\text { Depth Below } \\
\text { Sea Floor }(\mathrm{m})\end{array}$ & $\begin{array}{c}\text { Punch- } \\
\text { in }\end{array}$ & $\begin{array}{c}\text { Flow- } \\
\text { through }\end{array}$ & $\begin{array}{c}\text { Alkalinity } \\
(\mathrm{meq} / \mathrm{kg})\end{array}$ & $\begin{array}{c}\text { Salinity } \\
\text { (\%) })\end{array}$ & $\begin{array}{c}\text { Remarks } \\
\text { (Combination } \\
\text { Electrode } p \mathrm{H})\end{array}$ \\
\hline Surface/Seawater & & 8.24 & 8.23 & 2.27 & 34.4 & 8.31 \\
$1-3,144-150$ & 110.0 & 7.73 & 7.82 & 3.49 & 35.2 & 8.12 \\
$2-1,144-150$ & 217.5 & - & 7.19 & 2.28 & 34.4 & 7.45 \\
$3-4,144-150$ & 241 & 6.90 & 7.18 & 2.13 & 34.4 & 7.36 \\
\hline
\end{tabular}
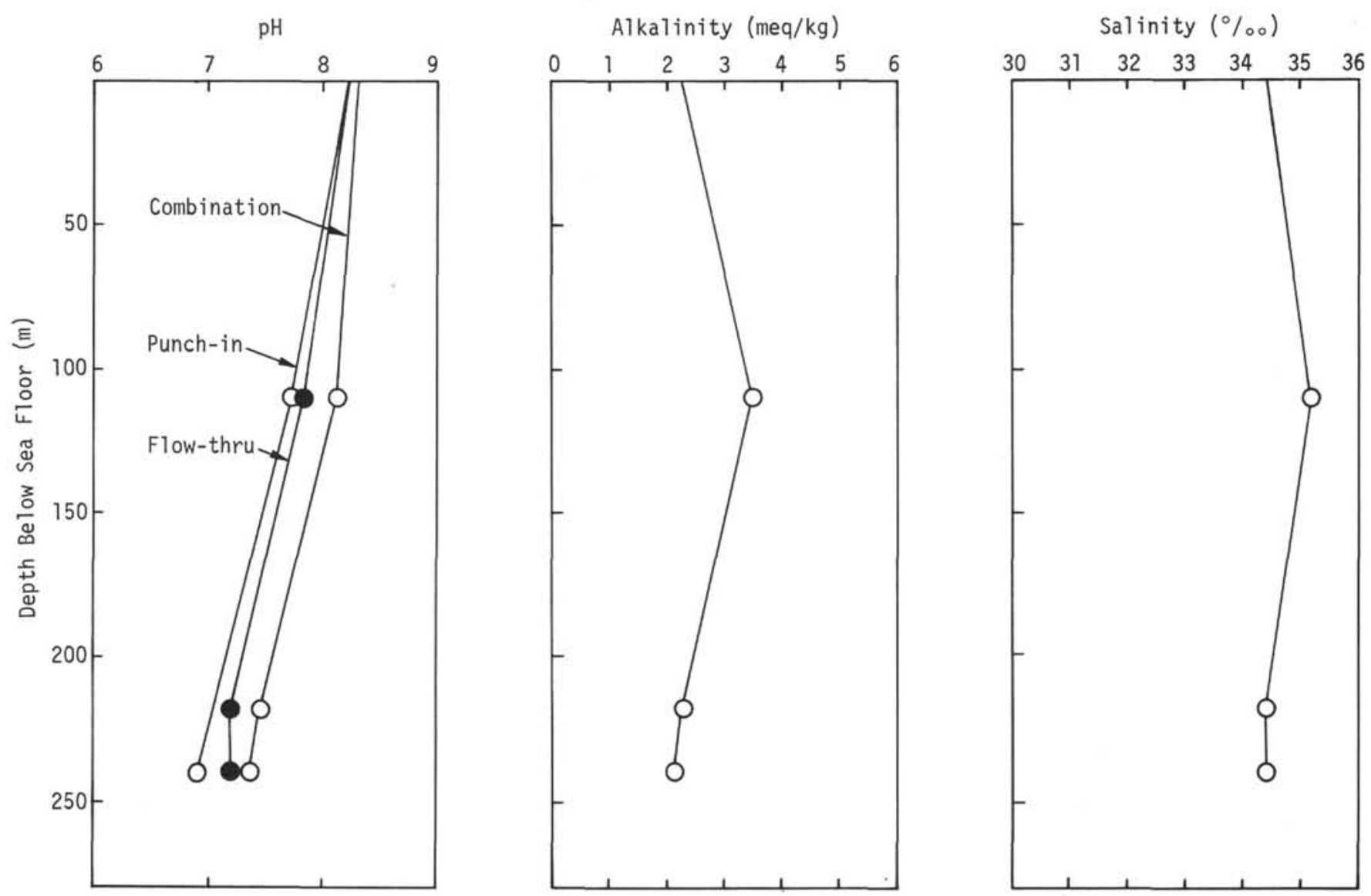

Figure 5. Graphic summary of geochemical data taken at Site 304.

\section{Alkalinity}

The maximum alkalinity of $3.49 \mathrm{meq} / \mathrm{kg}$ was obtained from the uppermost sample $(110 \mathrm{~m})$, a radiolarian-diatom ooze. The remaining two values decreased with aepth. The minimum value was 2.13 $\mathrm{meq} / \mathrm{kg}$ at 241 meters in a zeolitic pelagic clay.

\section{pH}

The $p \mathrm{H}$ of the interstitial water was lower than that of surface seawater and decreased with depth in the hole.

\section{Salinity}

As at the previous site, salinities remained relatively constant with depth. A salinity of $35.2 \%$ at 110 meters was the only value that differed from the surface seawater value of $34.4 \%$.

\section{PHYSICAL PROPERTIES}

\section{Wet Bulk Density and Porosity of Soft Sediments}

The wet bulk density of the soft, moderately intensely disturbed sediments recovered at Site 304 was measured continuously, using the gamma-ray attenuation porosity evaluator (GRAPE). The density is fairly constant through each cored interval and increases from 1.23 $\mathrm{g} / \mathrm{cc}$ in the radiolarian diatom ooze of Core 1 to 1.45 $\mathrm{g} / \mathrm{cc}$ in the pelagic clay of Core 2 . Two syringe samples were taken from Core 1 and one sample from Core 2 as an independent measure of the bulk density and porosity. The bulk density of the radiolarian diatom ooze and pelagic clay samples, 1.26 and $1.58 \mathrm{~g} / \mathrm{cc}$, respectively, agree quite well with the GRAPE values of 1.23 and 1.52 $\mathrm{g} / \mathrm{cc}$. The porosity is about $85 \%$ in the ooze and decreases to about $80 \%$ in the underlying pelagic clay. 
The higher density of the clay as compared to the biogenic ooze parallels the trend seen at Site 303 .

\section{Velocity Measurements}

The compressional wave velocity, $V p$, of the soft sediments and rocks was measured with a Hamilton frame. The $V p$ of the soft sediments was measured on the split cores, and that of the cherts and basalt was measured on fragments and core segments, respectively.

The $V p$ of the soft, moderately intensely disturbed, siliceous ooze and pelagic clay is about $1.50 \mathrm{~km} / \mathrm{sec}$. The $V p$ of the porcellanite ranges from 1.9 to $3.0 \mathrm{~km} / \mathrm{sec}$, and that of the chert ranges from 4.0 to $5.3 \mathrm{~km} / \mathrm{sec}$. The $V p$ of the basalt increases from $5.2 \mathrm{~km} / \mathrm{sec}$ at the top of the unit to $5.6 \mathrm{~km} / \mathrm{sec} 1$ meter below and remains constant to the bottom of the hole. The higher $V p$ of the basalt at this site as compared with that at the previous site $(4.5 \mathrm{~km} / \mathrm{sec})$ is probably due to the fact that this basalt is less finely crystalline and also less fractured.

\section{CORRELATION OF SEISMIC REFLECTION PROFILES WITH DRILLING RESULTS}

The "acoustic stratigraphy" at Site 304 is based on seismic reflection profiles recorded while approaching and leaving the site (Figure 3 ) and from a sonobuoy profile recorded while on site (Figure 6). The underway profiles show a section very similar to that observed at Site 303 which consist of a faintly stratified upper interval down to about $0.30 \mathrm{sec}$ below the sea floor. At that depth a thick, strongly reflective zone is encountered. Within this zone a very thin transparent interval is barely discernible. However, it is clearly visible on the sonobuoy record where the highly reflective zone appears composed of two discrete reflectors at $0.30 \mathrm{sec}$ and 0.40 sec subbottom, respectively. The lowermost of these reflectors is the acoustic basement.

The lithology of the samples recovered at Site 304 is very similar to that of the samples from Site 303, and the acoustic correlation between the two sites is well documented on the basis of an uninterrupted seismic profile. Therefore, although the upper interval was only sparsely sampled at Site 304, the correlation between the two sites is rather well established.

The upper interval ( $0-0.30 \mathrm{sec}$ subbottom) again correlates well with the diatom radiolarian ooze grading down to zeolitic pelagic clay (Cores 1-3). The first chert was encountered at the base of Core 3 at 244 meters subbottom. A major decrease in the drilling rate is also observed at that depth (top of Core 4) and chert is very abundant from that level down to the basement. This lithological change is believed to correspond to the top of the highly reflective zone on the profiles and to the first strong reflector on the sonobuoy record. This correlation allows for an average interval velocity of 1.63 $\mathrm{km} / \mathrm{sec}$ for the upper interval. This value is identical to the one computed for the same interval at Site 303.

The second major lithological change was encountered at 335 meters subbottom where the top of the basaltic basement was reached. This lowermost lithological boundary corresponds undoubtedly to the lowermost reflector or acoustic basement observed at $0.40 \mathrm{sec}$ on both the underway profiles and the sonobuoy record.

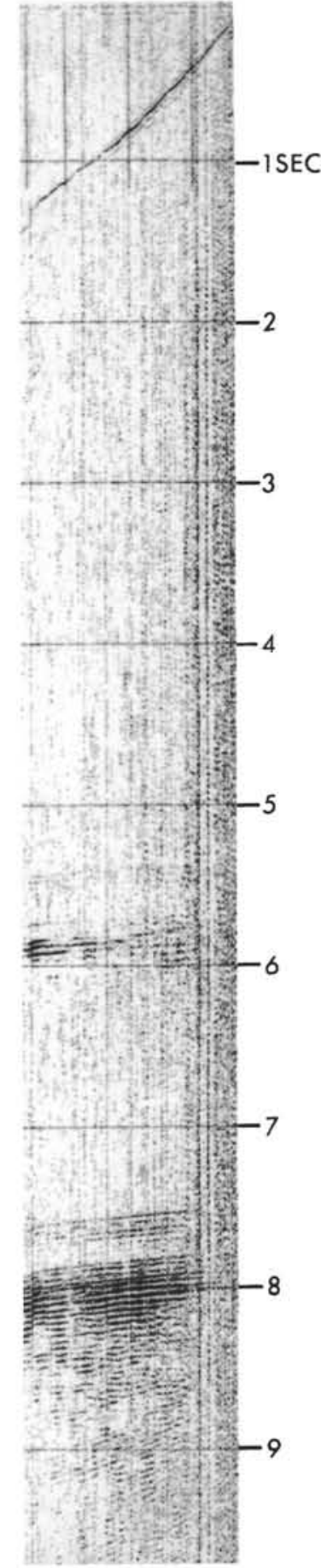

Figure 6. Sonobuoy record taken at Site 304.

The computed average velocity for the interval between the two reflectors is about $2.7 \mathrm{~km} / \mathrm{sec}$, which could account for the very cherty zeolitic pelagic clay and nannofossil ooze recovered at the base of the sedimentary section and is somewhat similar to the values obtained at Site 303 for the same type of sediment (2.8-3.0 $\mathrm{km} / \mathrm{sec}$ ).

The correlation between the lithology and the profiles is summarized in Figure 7. 


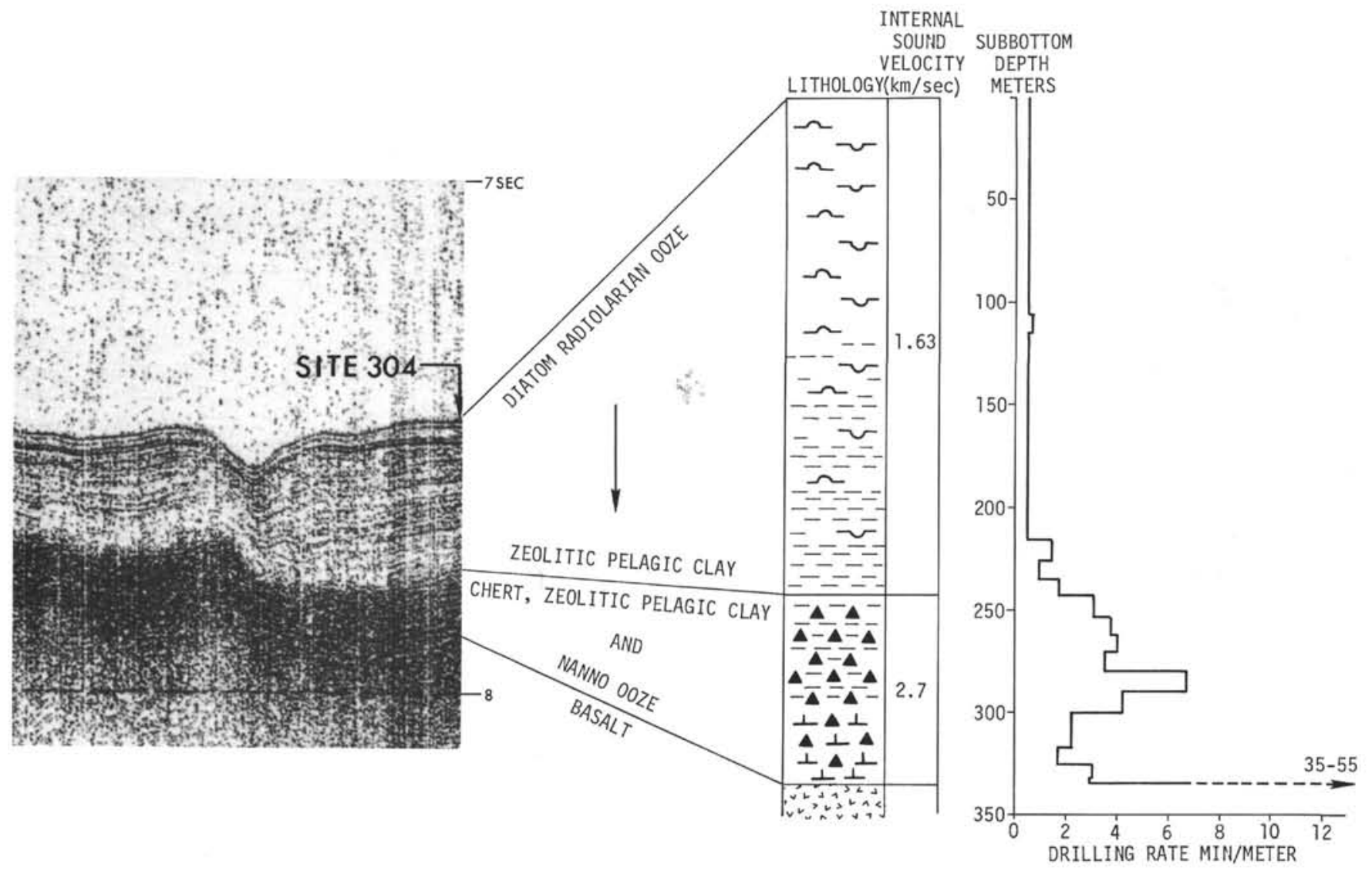

Figure 7. Correlation of seismic reflection profile with drilling results at Site 304.

\section{SEDIMENTATION RATES}

Ages, lithologies, and coring pattern at Site 304 are similar to those at Site 303. The upper section contains a gray diatom ooze and an orange radiolarian clay. At Site 304 these lithologies were recovered in only two cores, however, the sequence and paleontologic age are similar to those at Site 303 and suggest approximately the same sedimentation rate, $17 \mathrm{~m} / \mathrm{m} . \mathrm{y}$. at 304 and 16 $\mathrm{m} / \mathrm{m} . \mathrm{y}$. at 303 .

An uncored interval of 19 meters between Neogene(?) Core 2 and Cretaceous Core 3 may contain the nonfossiliferous, brown pelagic clay that predominates in Core 2. From the standpoint of sedimentation rates, the oldest Neogene (middle or late Miocene) sample of Site 304 is about 70 m.y. younger than the Early Late Cretaceous Core 3. An erosion surface between the Miocene and Early Late Cretaceous is implied at Site 304 just as it was at Site 303. The calculated error bars for Cretaceous Cores 3 to $15(235-335 \mathrm{~m})$ are so large and the core recoveries are so small that sedimentation rates would be too speculative.

\section{BIOSTRATIGRAPHIC SUMMARY}

\section{Cenozoic}

Core 1 (106-115 m) contains well-preserved, siliceous microfossils dominated by diatoms. The silicoflagellates belong to the Dictyocha fibula Zone (late Miocene or early Pliocene). The Radiolaria from the same core are of late Miocene age.
Core 2 (at $216 \mathrm{~m}$ ) consists mainly of cavings with common and well-preserved radiolarians of late Miocene age and scarce silicoflagellates of probable late Miocene age.

\section{Mesozoic}

The only microfossils found in Cores 3 to 11 (235-318 $\mathrm{m})$ are Radiolaria in quite variable amounts and preservation. The age assignments have been determined by correlating the Radiolaria with those at Sites 305 and 306 where ages are controlled by calcareous fossils. In the Neocomian there is approximately a one-stage difference between the age assignments based on foraminifera and those based on nannoplankton. Because no value judgments can be made, the complete ranges given for both the foraminifera and the nannoplankton are used in assigning ages to the corresponding cores with Radiolaria only in Hole 304 . Therefore some rather long ranges result. Those from Core 3 (235-244 $\mathrm{m})$ are attributed to the late Albian and Core 4 (244-253 $\mathrm{m})$ to the Albian to Aptian. The Radiolaria of Cores 5 to 7 (253-281 m) indicate an Aptian to Barremian age, whereas those of Core $8(281-290 \mathrm{~m})$ and Core 9 (290$299 \mathrm{~m}$ ) are Aptian to Barremian or Hauterivian and Barremian to Hauterivian or Valanginian, respectively. Calcareous microfossils occur only in the lowermost four sedimentary cores, Cores 12 to $15(318-335 \mathrm{~m})$. Coccoliths recovered from thin coatings of chert (Core 12) and basalt (Core 15) suggest an Early Cretaceous age without more precision. Assemblages from Cores 13 and 
14 are richer and more diversified and are characteristic for the interval corresponding to the Valanginian to Hauterivian.

Foraminifera are only found in Cores 13 and 14 . The well-preserved faunules consist mainly of small delicate lagenids and such arenaceous species as Dorothia kum$m i$, D. praeoxycona, and $D$. hauteriviana. They are attributed to the Hauterivian or Barremian.

A comparison of the age of the sediments immediately overlying the basalts at Sites 303 (M-4) and 304 (M-9) is difficult. The postulated age difference between the two lineations (5 m.y., according to Larson and Pitman, 1972 , fig. 5) is probably smaller than the biostratigraphic resolution which can be achieved by the zonations available at present for the subdivision of Early Cretaceous deep-sea deposits.

\section{Foraminifera}

Cores 1 through 12 contain no foraminifera. "Cuttings" corresponding to Core 13 have furnished a very poor microfauna which is mainly composed by relatively well-preserved small and delicate lagenids. Core 14 contains a rather rich but poorly preserved microfauna dominated by lagenids and Dorothia spp. (for faunal lists, see Luterbacher, Early Cretaceous foraminifera, this volume). The attribution of this core to the Hauterivian or Barremian ("Interval with Dorothia hauteriviana") is based on the co-occurrence of Dorothia kummi, $D$. praeoxycona, and $D$. hauteriviana.

\section{Coccoliths}

Coccoliths occur only in the lowest four cores above basalt (Cores 12-15; 318-335 m). In Cores 12 and 15, coccoliths were recovered only from thin coatings (originally laminae?) on chert fragments. These assemblages have limited diversity and suggest Early Cretaceous. The best assemblages, from the carmine and orange clays of Cores 13 and 14 , contain more definitive assemblages that indicate Valanginian to Hauterivian.

Although the basal clays of Cores 13 and 14 are lithologically correlative to Core $8 \mathrm{~A}$ at Site 303 , preservation and diversity of coccoliths are distinctly better in the two Site 304 cores. Discrimination of the younger Site 303 on magnetic anomaly M-4 from the older Site 304 on magnetic anomaly M-9 is difficult not only because of different preservation, but also because the broad stratigraphic resolution of planktonic microfossils in the Early Cretaceous (zones of 3 to 7 m.y. duration) approaches the extrapolated age difference of $5 \mathrm{~m}$.y. between these two magnetic anomalies.

\section{Diatoms and Silicoflagellates}

Late Miocene or early Pliocene diatoms and silicoflagellates are common to abundant and well preserved throughout Core 1 (106-115 m). Mesocena circulus constitutes $4 \%$ to $17 \%$ of the silicoflagellate population, suggesting proximity to the Miocene-Pliocene boundary. Dictyocha predominates over Distephanus, indicating warm-water conditions.

At the top of Core 2, Section 1 (216-217 m), cavings of an orange-colored diatom-bearing radiolarian clay, resembling the Core 4 recovery at Site 303, contain a probable early late Miocene silicoflagellate assemblage. The poorly preserved assemblage contains Cannopilus sphaericus, Dictyocha pseudofibula, Distephanus longispinus $\mathrm{s}$. ampl., and $D$. schaunislandii, which suggest an older age than the comparable assemblages for Site 303 .

Deeper samples are barren of siliceous phytoplankters.

\section{Radiolaria}

In Core 1 Radiolaria are common and well preserved. Core 2 contained only fish teeth, except for a sample of moderate yellowish-brown pelagic clay (Sample 2-1, 80$82 \mathrm{~cm}$ ) probably representing cavings from up-hole, which contained common, well-preserved Radiolaria. No calcareous fossils are present in the Neogene section recovered from Site 304.

Core 1, at a depth of 106 to 115 meters below the sediment surface, is late Miocene Stichocorys peregrina Zone and the cavings of Core 2, at a depth of 216 meters, are late Miocene, Ommatartus antepenultimus Zone.

No siliceous fossils other than Radiolaria were recovered from samples of clay, mudstone, and chert in Cores 3 to 15 . In general, the samples of mudstone contained common, well-preserved Radiolaria. Abundance and preservation of Radiolaria in the cherts varied from common to very rare and moderate to very poor. No consistent pattern of abundance or preservation in relation to the color of the chert could be discerned. In the lower part of the hole, Cores 12 to 15 contain calcareous fossils. Radiolaria in these cores are rare to very rare, and poor to very poor, except in Core 13 , for which the recovery was very poor, and in which Radiolaria are entirely absent.

The age assignments for the Radiolaria are based on correlations with Radiolaria in Holes 305 and 306 (see Foreman, Figure 1, this volume). Core 3, at a depth of 235 to 244 meters, is late Albian, Dictyomitra somphedia Zone and Core $4(244-253 \mathrm{~m})$, Albian to Aptian, Acaeniotyle umbilicata Zone. Cores 5 to 7 at depths of 253 to 281 meters, are considered to be Aptian to Barremian and Cores 8 and 9 (281-299 m), Aptian to Barremian and Barremian to Hauterivian or Valanginian, respectively. Cores 5 and 6 belong to the Acaeniotyle umbilicata Zone and Cores 7 to 9 to the Eucyrtis tenuis Zone.

In samples 8-1, 130-132 cm (clay) and 9-1, 101-103 cm (mudstone) a well-preserved fauna is present with only a few elements in common with the radiolarian fauna recovered from the chert. It resembles very much the fauna described by Tan Sin Hok (1927) from the island of Roti and is considered contemporaneous with the Radiolaria in the cherts, differing only as a result of diversity in preservation. Table 4 is a summary of the biostratigraphy of Site 304 .

\section{Other Microfossils}

Thin sections from a carbonate vein in the basalt (Sample 16-2, 45-60 cm) are rich in well-preserved Favreina sp. aff. F. salevensis (Paréjas) (coprolites of crustaceans, Lehmann, this volume). 
TABLE 4

Distribution, Age, and Frequency of Investigated Microfossils

\begin{tabular}{|c|c|c|c|c|c|c|c|c|c|}
\hline \multirow{2}{*}{ نั } & \multirow[b]{2}{*}{ Depth $(m)$} & \multirow{2}{*}{ 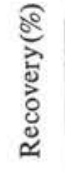 } & \multicolumn{3}{|c|}{ Foraminifera } & \multirow{2}{*}{\multicolumn{2}{|c|}{$\begin{array}{c}\text { Calcareous } \\
\text { Nannoplankton }\end{array}$}} & \multirow{2}{*}{\multicolumn{2}{|c|}{ Radiolaria }} \\
\hline & & & $\frac{\vec{z}}{\tilde{a}}$ & ల్ల & & & & & \\
\hline 1 & $105.5-115.0$ & 58 & - & - & - & - & - & o & Late Miocene \\
\hline 2 & $216.0-225.5$ & 29 & - & - & - & - & - & o & Late Miocene \\
\hline 3 & $235.0-244.0$ & 100 & - & - & - & - & - & 0 & Late Albian \\
\hline 4 & $244.0-253.0$ & 1 & - & - & - & - & - & 0 & Albian \\
\hline 5 & $253.0-262.5$ & 4 & - & - & - & - & - & * & $\begin{array}{l}\text { Aptian/ } \\
\text { Barremian }\end{array}$ \\
\hline 6 & $262.5-271.5$ & 1 & - & - & - & - & - & + & $\begin{array}{l}\text { Aptian// } \\
\text { Barremian }\end{array}$ \\
\hline 7 & $271.5-281.0$ & 4 & - & - & - & - & - & o & $\begin{array}{l}\text { Aptian/ } \\
\text { Barremian }\end{array}$ \\
\hline 8 & $281.0-290.0$ & 10 & - & - & - & - & - & o & $\begin{array}{l}\text { Barremian/ } \\
\text { Hauterivian } \\
\text { or Valanginian }\end{array}$ \\
\hline 9 & $290.0-299.5$ & 5 & - & - & - & - & - & o & $\begin{array}{l}\text { Barremian/ } \\
\text { Hauterivian } \\
\text { or Valanginian }\end{array}$ \\
\hline 10 & $299.5-308.5$ & 4 & - & - & - & - & - & - & - \\
\hline 11 & $308.5-318.0$ & 3 & - & - & - & - & - & - & - \\
\hline 12 & $318.0-327.0$ & 3 & - & - & - & + & Early Cretaceous & - & - \\
\hline 13 & $327.0-331.0$ & 1 & - & + & - & o & $\begin{array}{l}\text { Hauterivian/ } \\
\text { Valanginian }\end{array}$ & - & - \\
\hline 14 & $331.0-334.5$ & 43 & - & $*$ & $\begin{array}{l}\text { Barremian/ } \\
\text { Hauterivian }\end{array}$ & - & $\begin{array}{l}\text { Hauterivian/ } \\
\text { Valanginian }\end{array}$ & - & - \\
\hline 15 & $334.5-337.5$ & 77 & & & & + & Early Cretaceous & & \\
\hline 16 & $337.5-343.0$ & 96 & & & SALT & & & & \\
\hline 17 & $343.0-347.0$ & 13 & & & & & & & \\
\hline
\end{tabular}

Note: • abundant; o common; ${ }^{*}$ frequent; + rare; - absent.

\section{SUMMARY AND CONCLUSIONS}

The primary purpose of drilling at Site 304 was to date the sediments overlying basement at magnetic anomaly M-9. Thus, the determination of an Early Cretaceous age for the oldest recovered sediments is the most significant result of this site. This provides further confirmation of the correlation between the Japanese and Phoenix magnetic lineations and is a significant calibration point for the time scale of Mesozoic magnetic reversals.

As at Site 303, there was little recovery of the soft, fossiliferous sediments near the base of the section, and the basement contact was not recovered. However, preservation and diversity of the fauna are much better than at Site 303, and the oldest sediments were recovered from within 3 meters of the basement contact. The age of the oldest sediments is probably a good determination of the age of anomaly M-9 and is certainly a better estimate of the basement age than was determined at Site 303. Although the preservation and diversity of fossils at Site 304 are far superior to those at Site 303 , the age determination suffers from the same problems as those encountered at Site 303. Here again, the foraminifera give a Barremian or Hauterivian determination, while the nannofossils point to Hauterivian or Valanginian. Thus, differences in age of Sites 303 and
304 cannot be determined from paleontology, although magnetic correlations predict Site 304 is older by perhaps 5 m.y.

These two sites can be combined with Site 166 on the Phoenix lineations to determine the best time scale for the younger portion of the M-sequence of magnetic reversals. Site 166 lies between M-7 and M-8 on the Phoenix lineations, so it should be stratigraphically between Sites 303 (M-4) and 304 (M-9), but closer to Site 304. Its oldest sediment is assigned to the late Hauterivian (foraminifera) or the late Hauterivian to early Aptian (nannofossils). As with Sites 303 and 304, the Radiolaria of Site 166 give a somewhat younger age. The Leg 17 paleontologists considered this discrepancy probably to be due to the imperfectly determined radiolarian stratigraphy. We shall use only the calcareous fossil ranges for this problem of time-scale calibration (Figure 8). The shortest age range at any of the three sites is given by the late Hauterivian foraminifera at Site 166. However, the best preserved and most diverse assemblage is probably that from the base of Site 304 . The best time scale that can be fit to all this information still appears to be the one proposed by Larson and Pitman (1972). Their time scale predicted the age of Site 303 to be early Barremian, which is about the middle of its foraminiferal range, but younger than its nannofossil range. Site 166 should be late Hauterivian which 


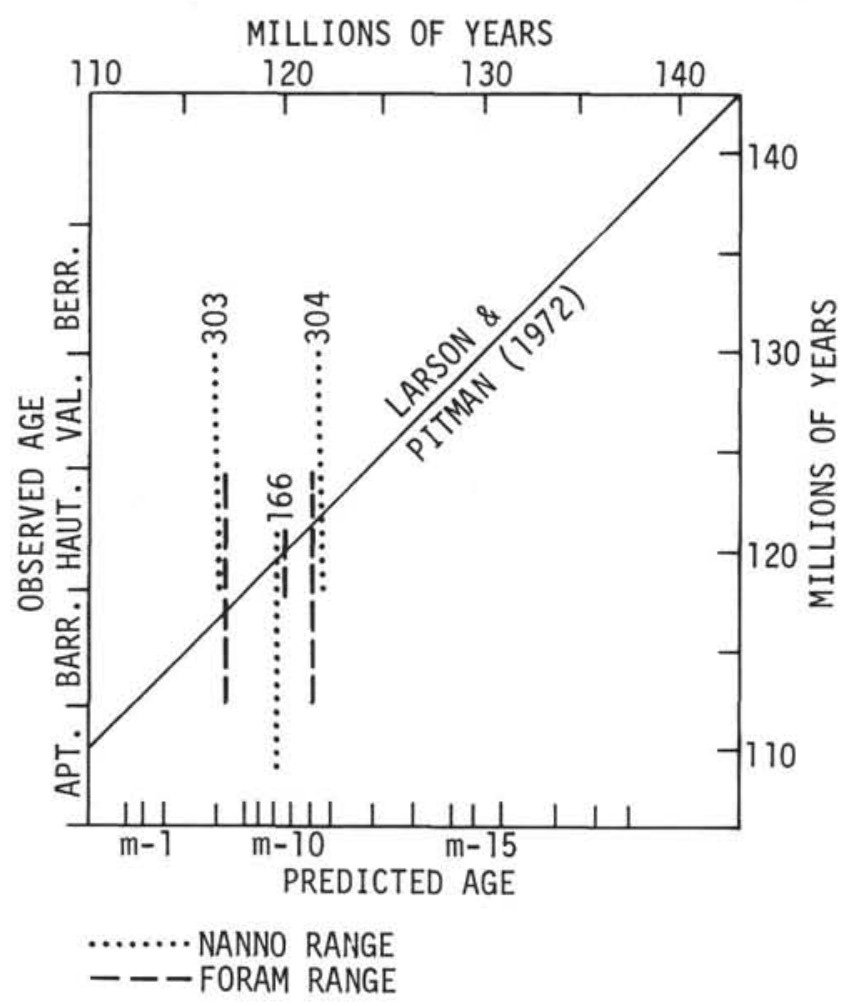

Figure 8. Plot of observed versus predicted aces showing the microfossil ranges of Sites 166, 303, and $304 \mathrm{com}$ pared to the time scale of magnetic reversals proposed by Larson and Pitman (1972). The ages are calibrated in millions of years after the Geological Society of London (Anon., 1964).

satisfies both its nannofossil and foraminiferal ranges. Site 304 should be mid-Hauterivian which is the average of the calcareous microfossil ranges at that site. Because of the multistage range of the fossils and the usual mismatch of nannofossil and foraminiferal ranges, this is not the only time scale that will satisfy these data, but it appears to be the most likely one.

The basalt recovered from the bottom of Site 304 is considerably different from that recovered from Site 303; no cooling unit boundaries were recovered except the uppermost one near the sediment-basement interface. Since most of the upper two basalt cores were recovered, it is unlikely that cooling unit boundaries were missed, and it appears that the uppermost unit is at least 8 meters thick. This may be a ponded lava flow or a sill, with the fine-grained nature of the entire unit pointing to the former interpretation.

The poor sediment recovery and gross age determinations in much of the Cretaceous section do not yield a precise picture of the passage of this part of the Pacific plate across the equator. However, the remnant inclination of the basalt indicates it was formed at $10^{\circ}$ south latitude (Larson and Lowrie, this volume). We believe the lower portion of the sedimentary section suggests that this area was generated at a ridge south of the equator, and the nannofossil ooze at the base of the section was laid down at the ridge crest. The ridge then subsided very rapidly, or the CCD was relatively higher than it is today, so that the equatorial crossing was not recorded by a thick carbonate sequence. Instead, the equatorial passage was recorded by the abundant siliceous microfossils, much of which have now become the Cenomanian to Valanginian cherty section. The fact that the Valanginian-Aptian section is much thicker here than at Site 303 (about $80 \mathrm{~m}$ versus about $40 \mathrm{~m}$ ) probably results from Site 304 being somewhat older, and also that it may have recorded the entire equatorial passage, whereas Site 303 was generated at the edge of the equatorial productivity zone.

The same stratigraphic breaks that were present at Site 303 also occur at Site 304. From Core 2 at 216 meters to Core 3 at 235 meters there is about an 80 to 90 m.y. transition from late Miocene to late Early Cretaceous (Albian). This gap or compressed section is not apparent on the profiler records. A complete summary of Site 304 is presented in Figure 9.

\section{REFERENCES}

Anonymous, 1964. Summary of the Phanerozoic time-scale: Geol. Soc. London Quart. J., v. 1205, p. 260-262.

Chase, T. E., Menard, H. W., and Mammerickx, J., 1971. Topography of the North Pacific: Institute of Marine Resources, University of California, San Diego.

Larson, R. L. and Pitman, W. C., III, 1972. Worldwide correlation of Mesozoic magnetic anomalies, and its implications: Geol. Soc. Am. Bull., v. 83, p. 3645-3662.

Tan Sin Hok, 1927. Over de Samenstelling en het onstaan van krijten mergelgesteenten van de Moluken: Verhandl. Mijnwezen Ned. Oost Indie. Jaarg. 1926, pt. 3, p. 5-165. 


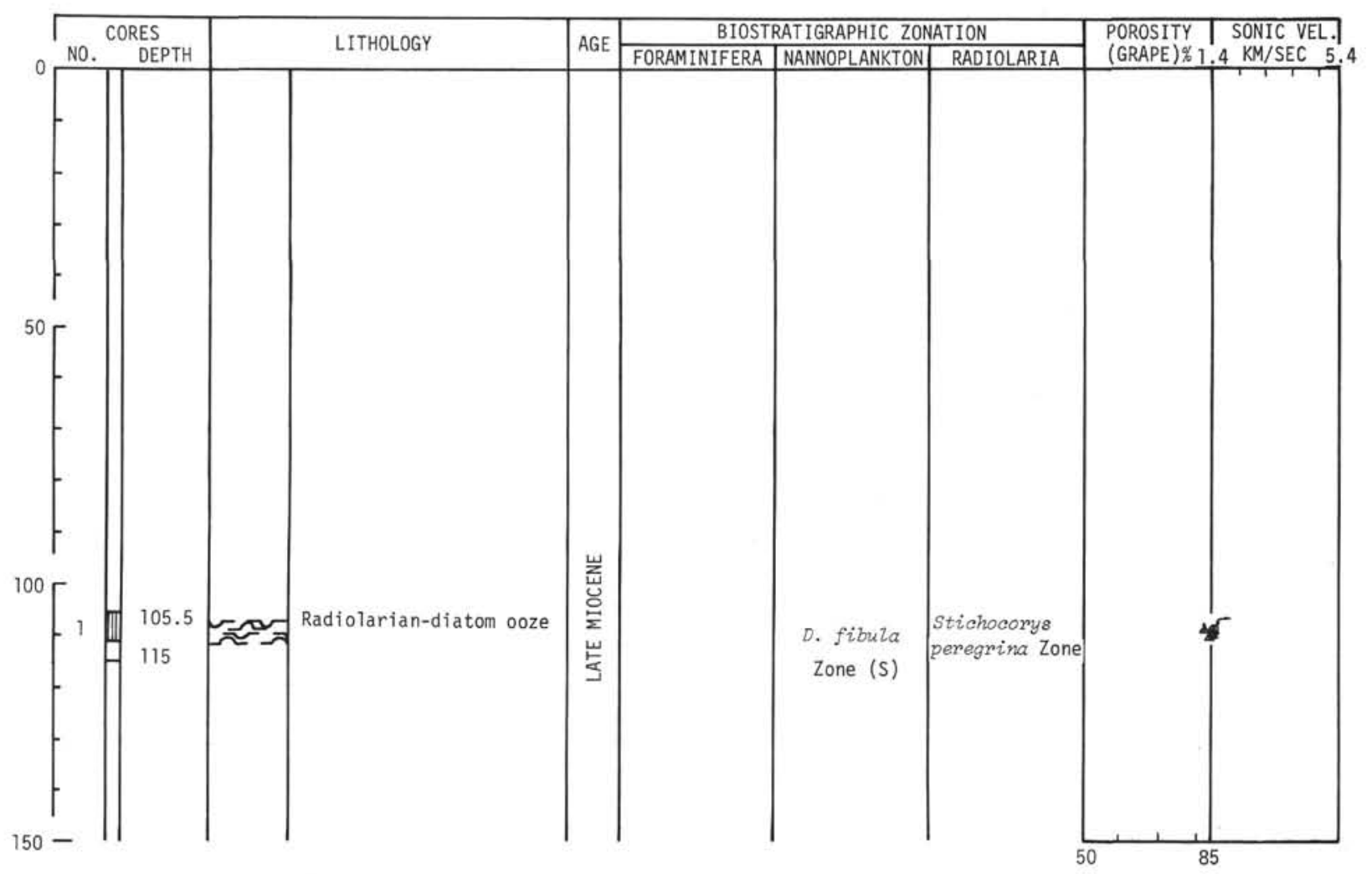

Figure 9. Summary of coring, lithology, biostratigraphy, and physical properties at Site 304.

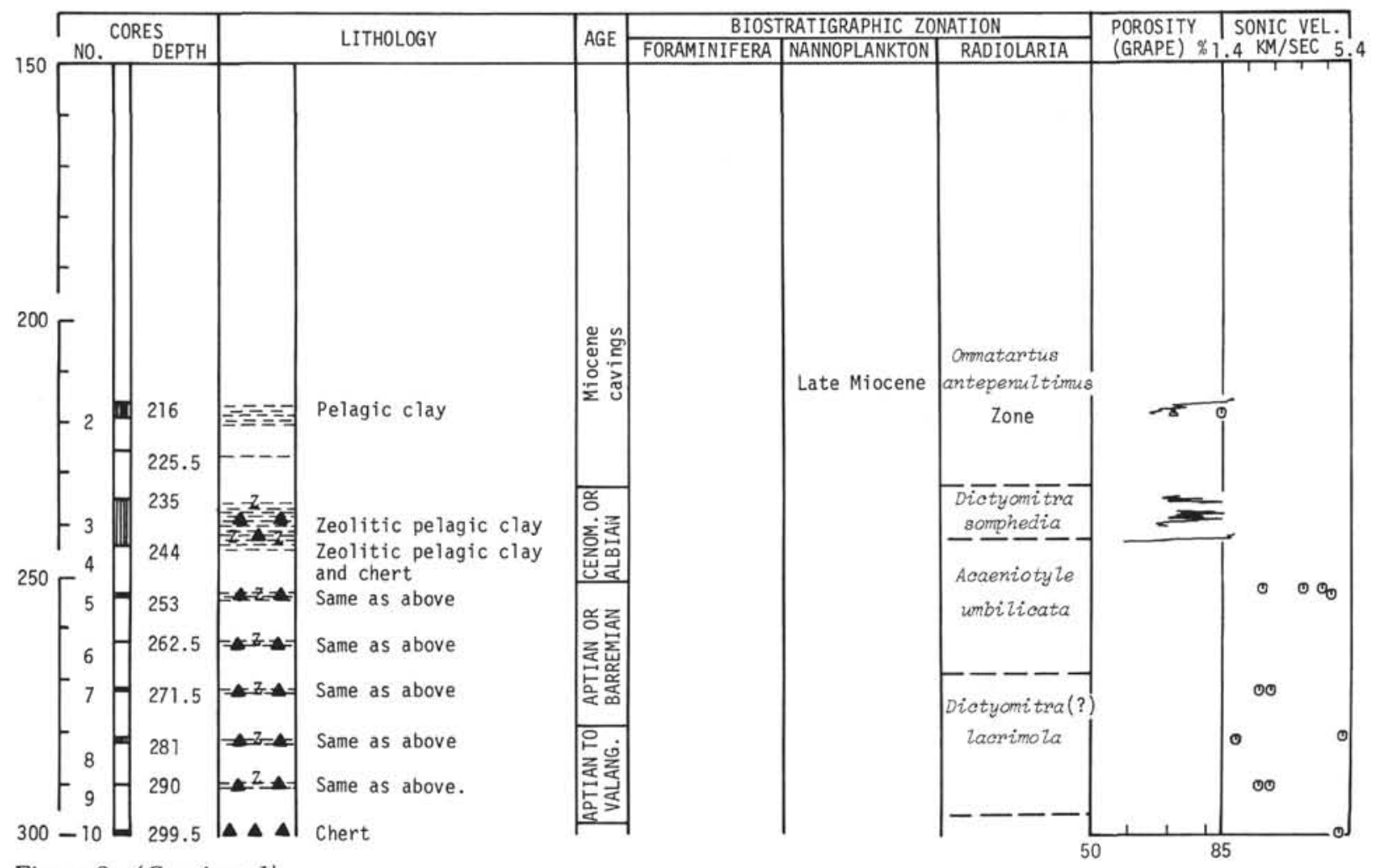

Figure 9. (Continued). 


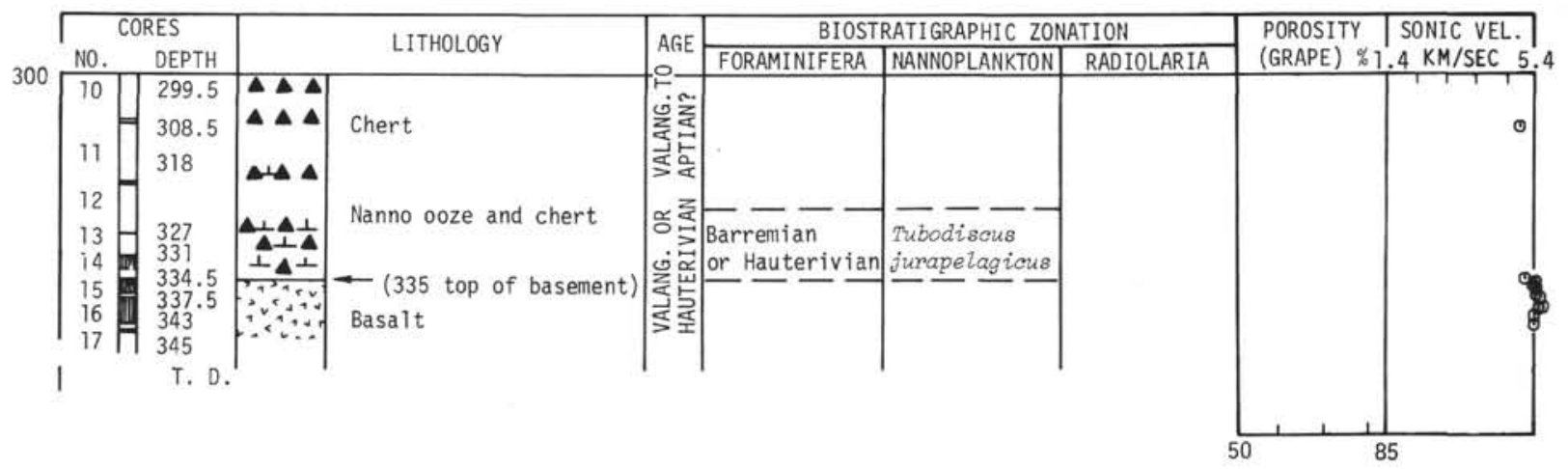

Figure 9. (Continued). 


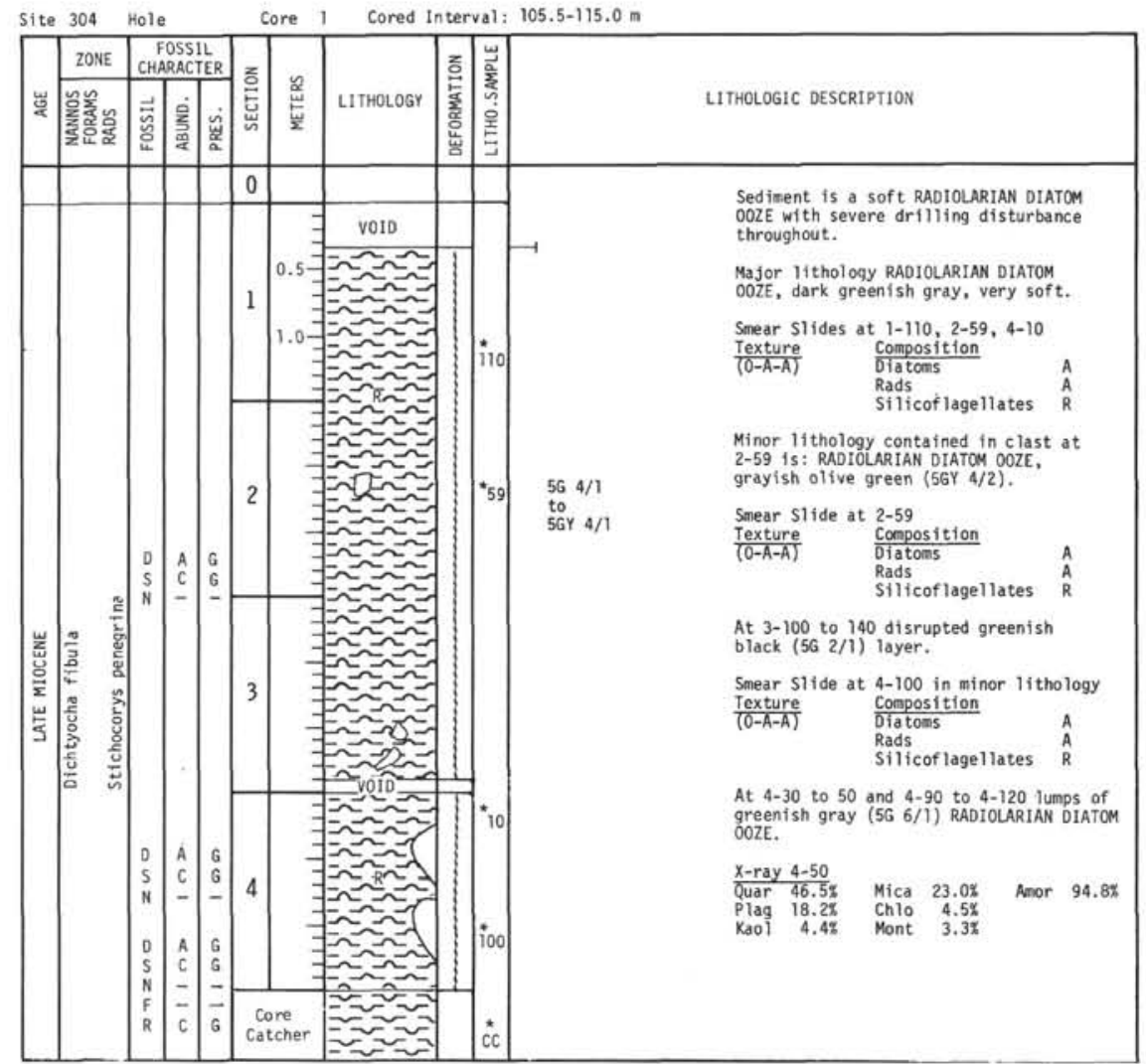

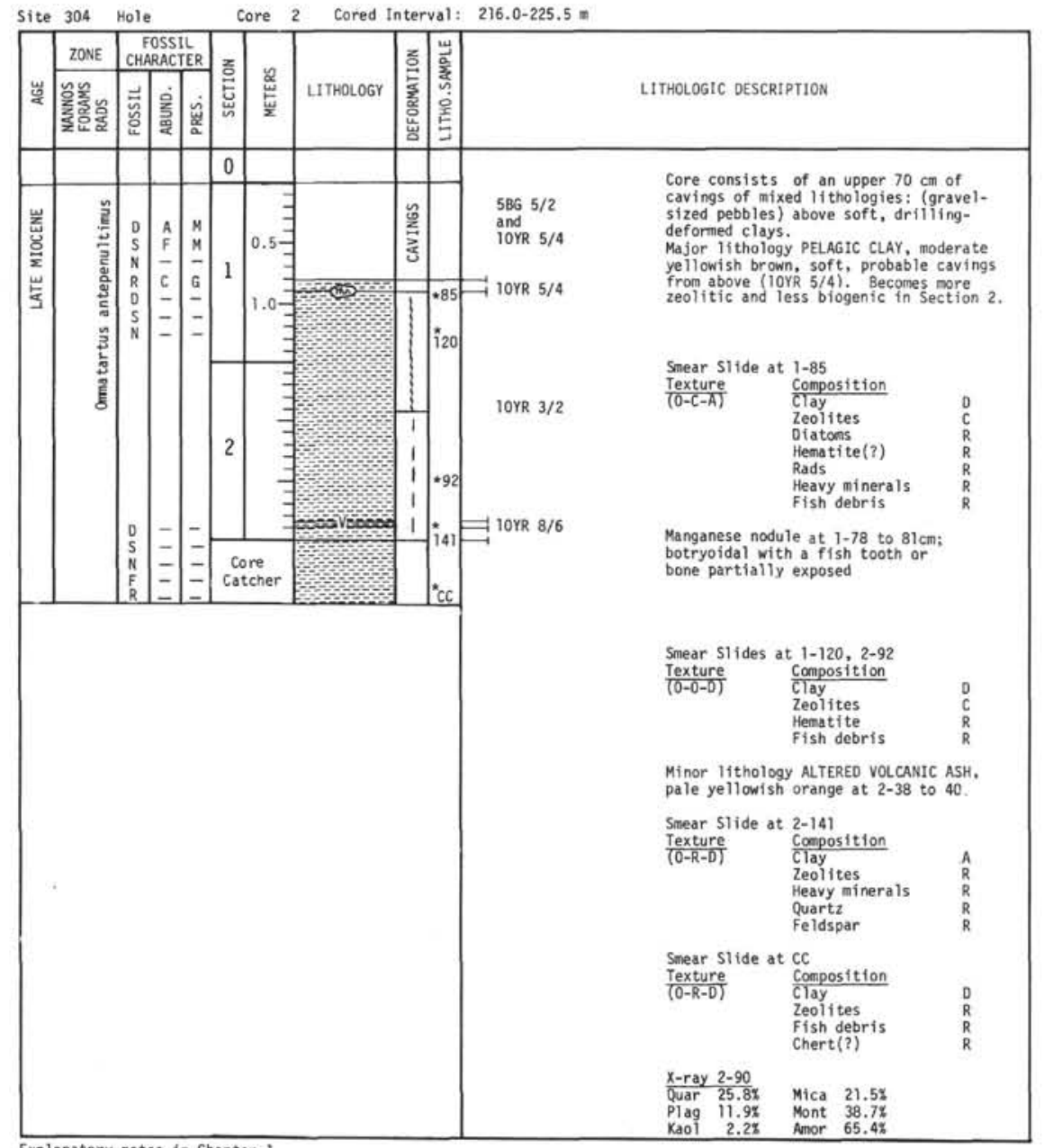




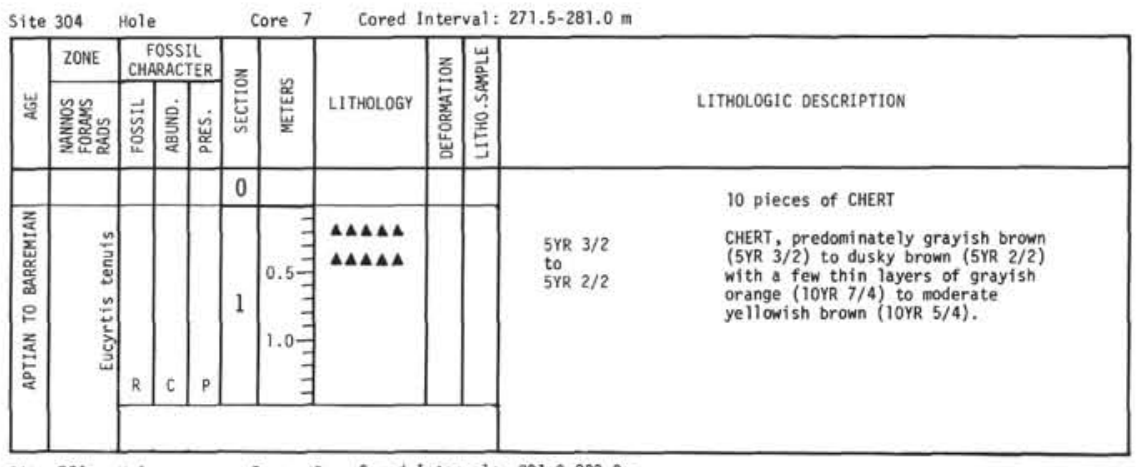

\begin{tabular}{|l|l|l|l|l|l|l|l|l|l|}
\hline Site 304 & Hole \\
\hline
\end{tabular}

Site 304 Hole Core 9 Cored Interva 1: 290.0-299.5 m

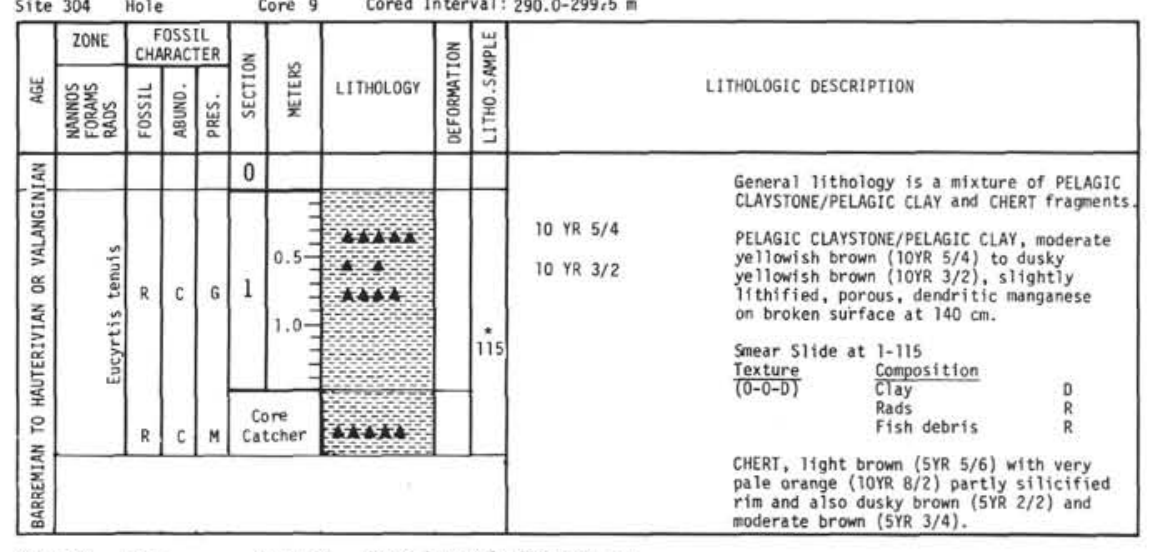

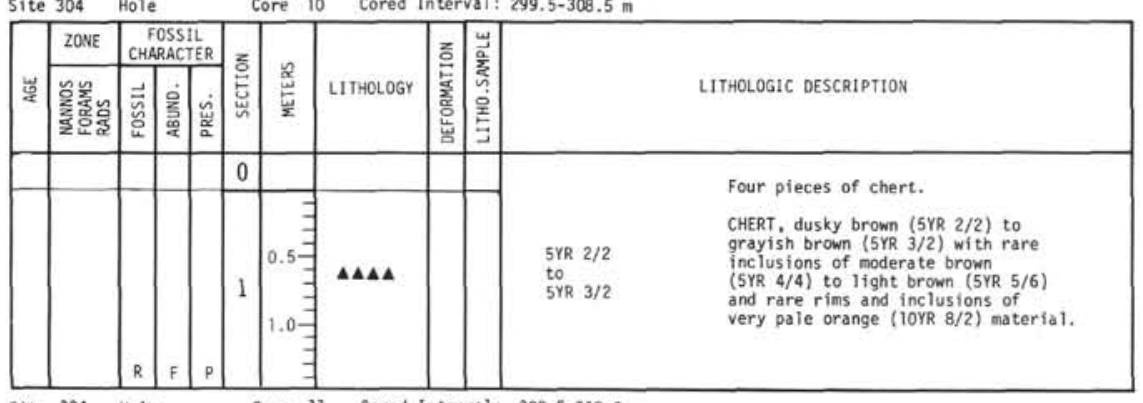

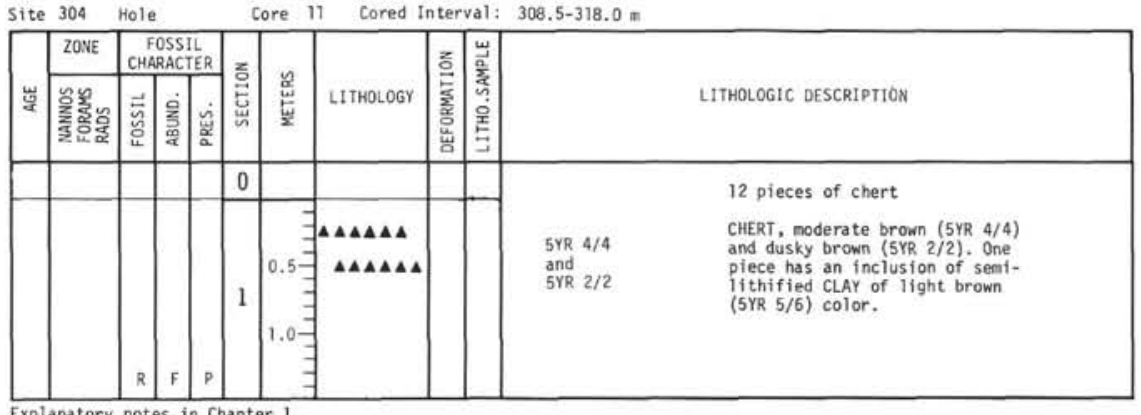

Explanatory notes in Chapter 1 


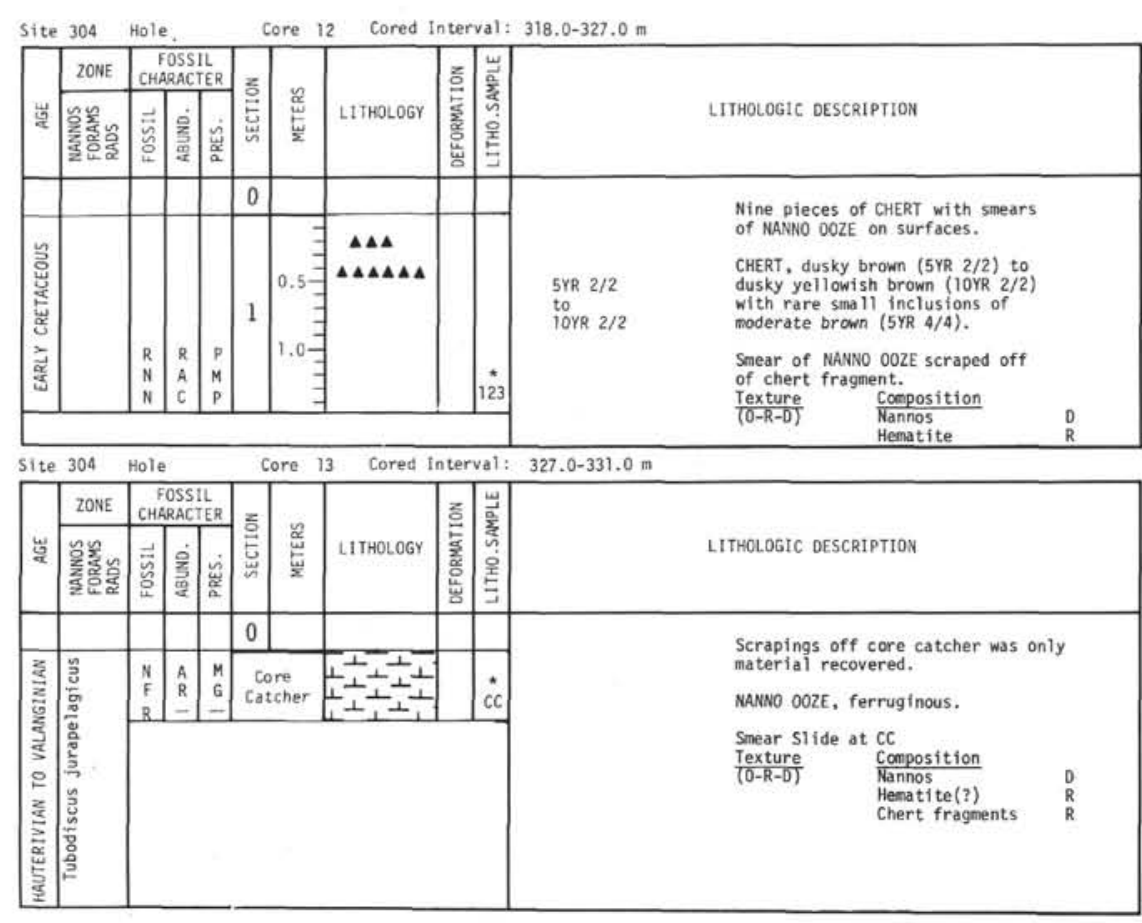

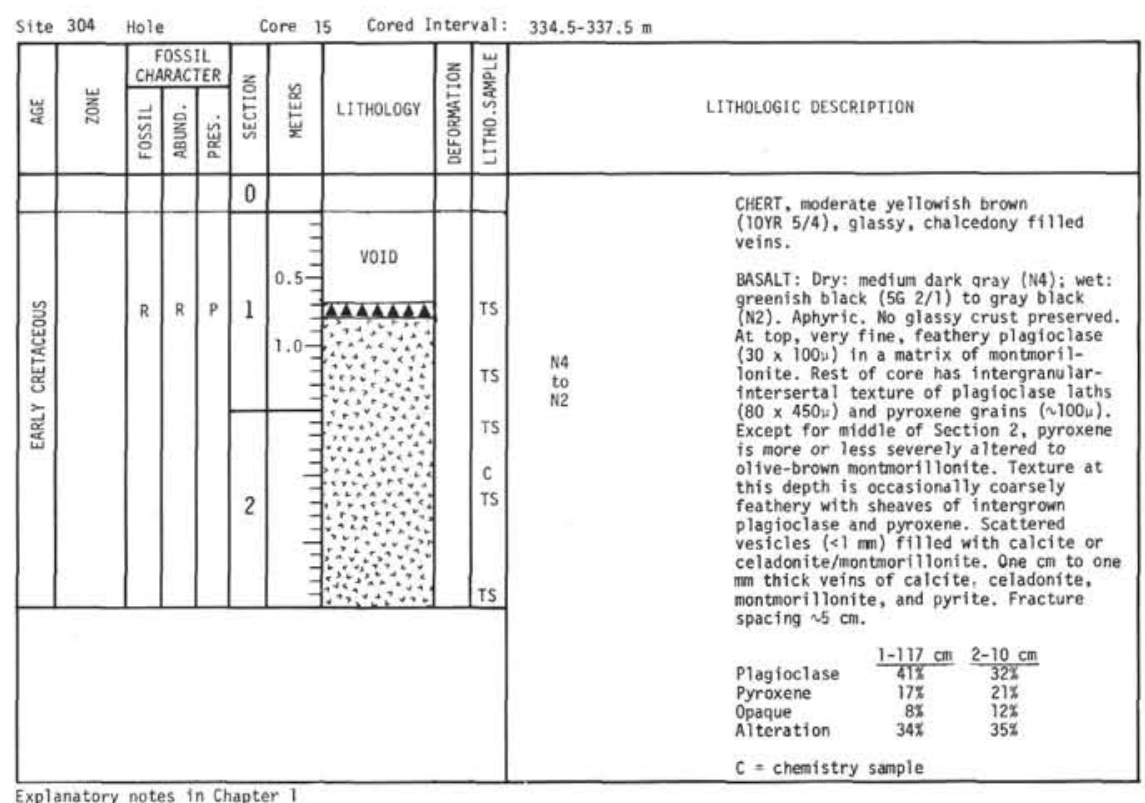

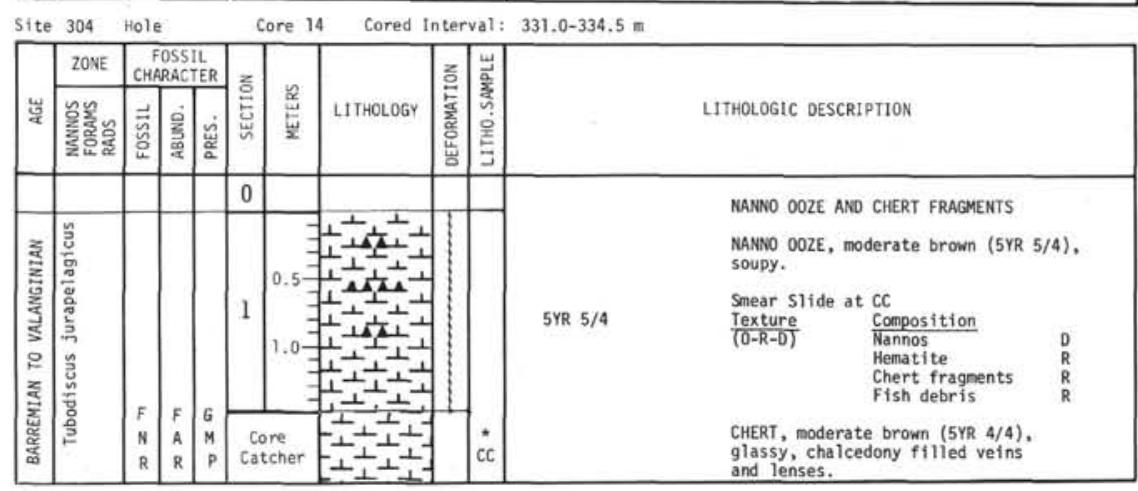




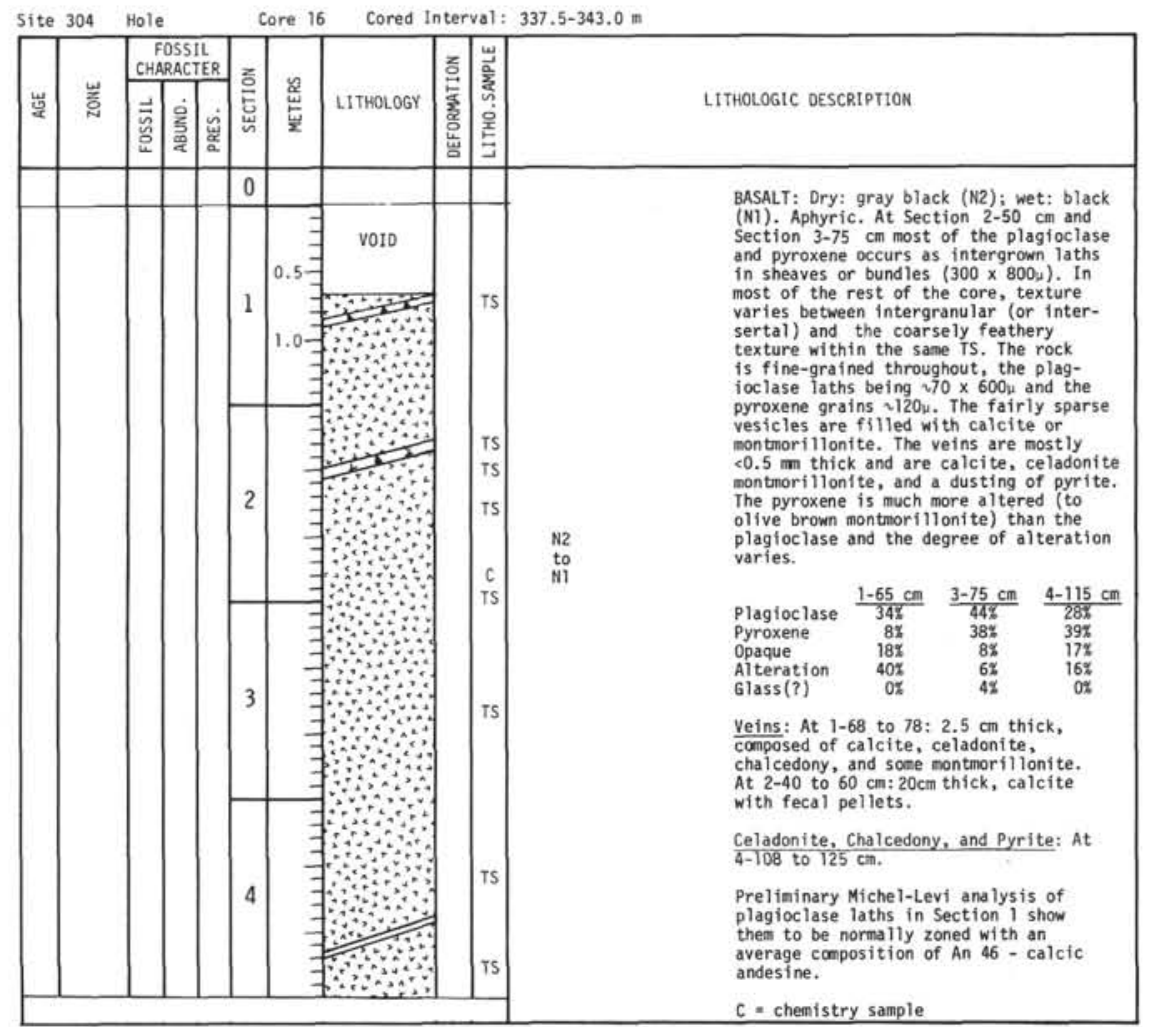

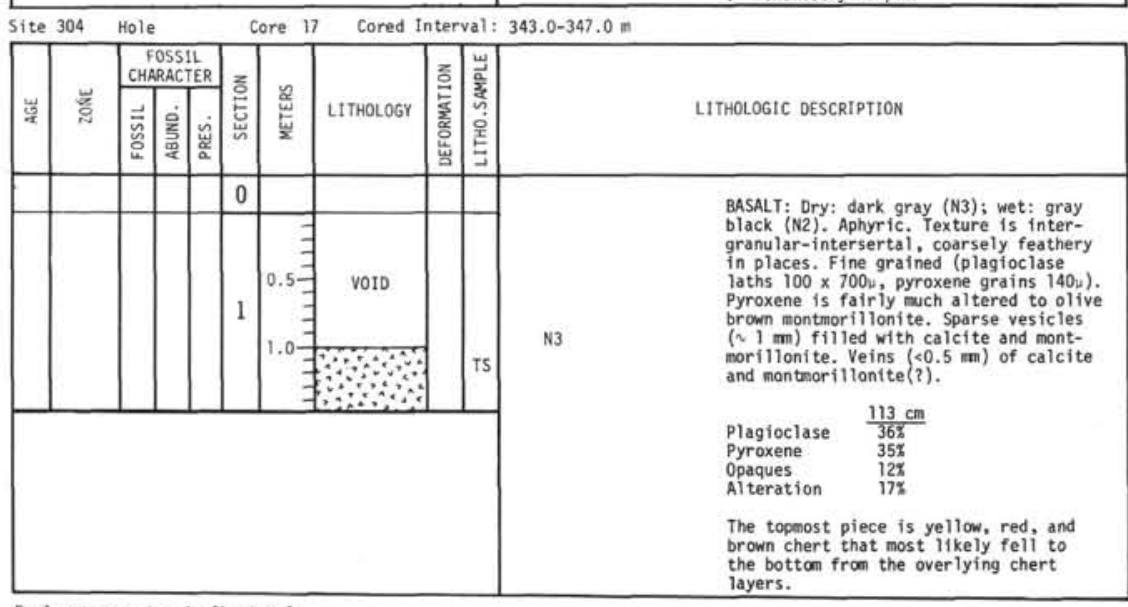

Explanatory notes in Chapter 1 
CORE 304-1

- $=$ GRAPE WET-BULK DENSITY, g/cC

- Syringe porosity, \% COMPRESSIONAL SOUND VELOCITY

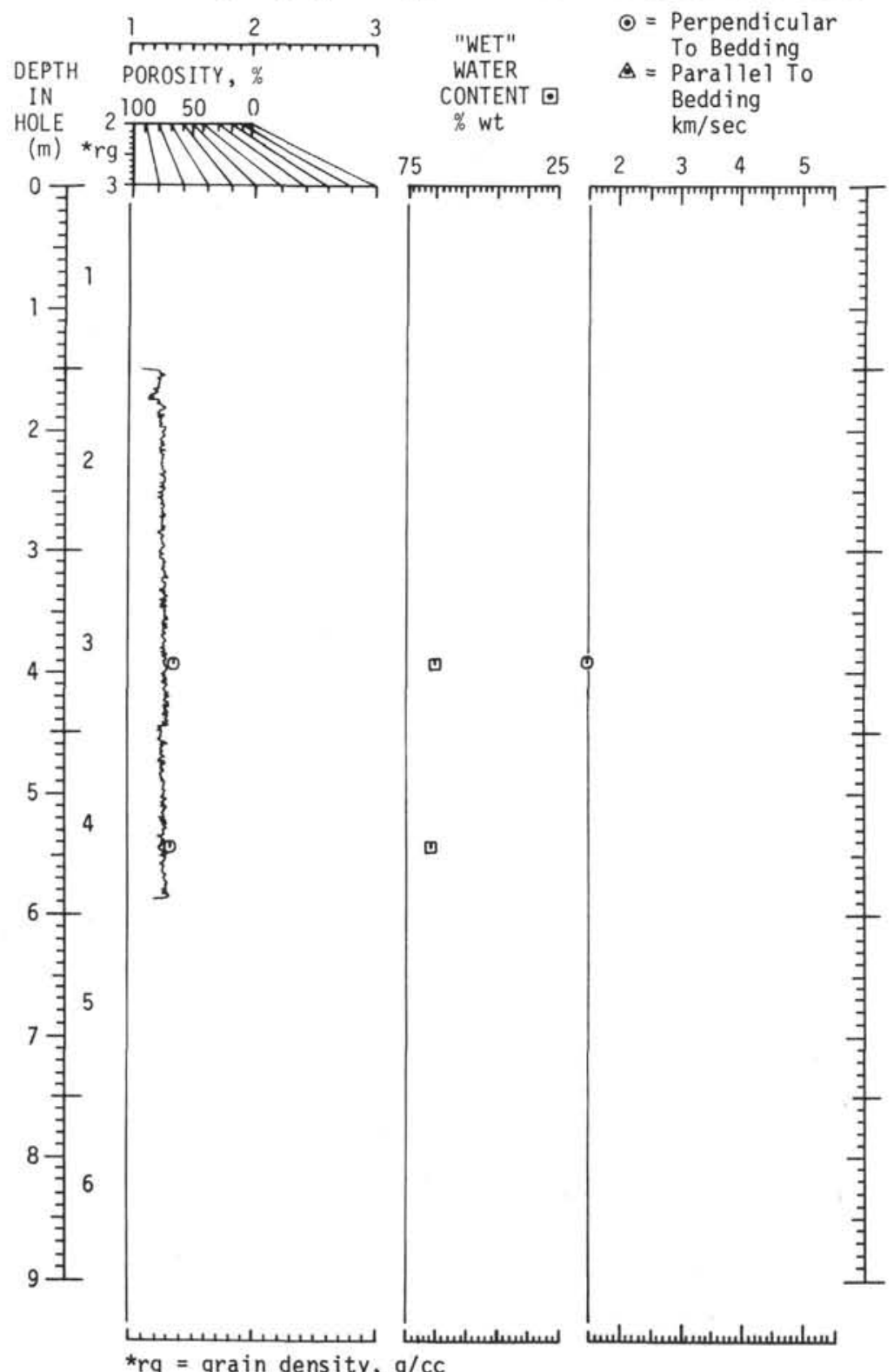

CORE 304-2

- = GRAPE WET-BULK DENSITY, g/cC

- Syringe porosity, \% COMPRESSIONAL SOUND VELOCITY

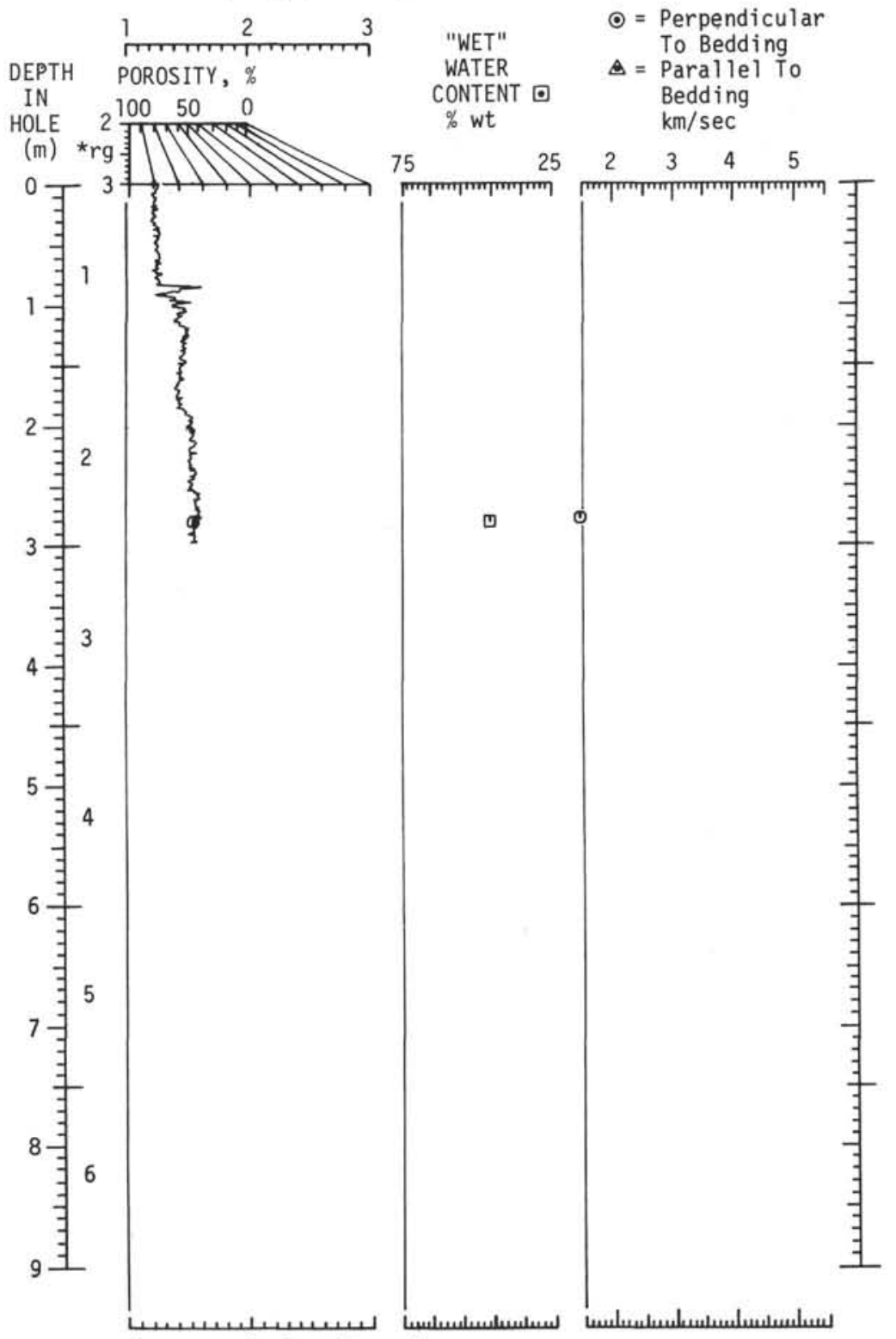


- Syringe porosity, \% COMPRESSIONAL SOUND VELOCITY

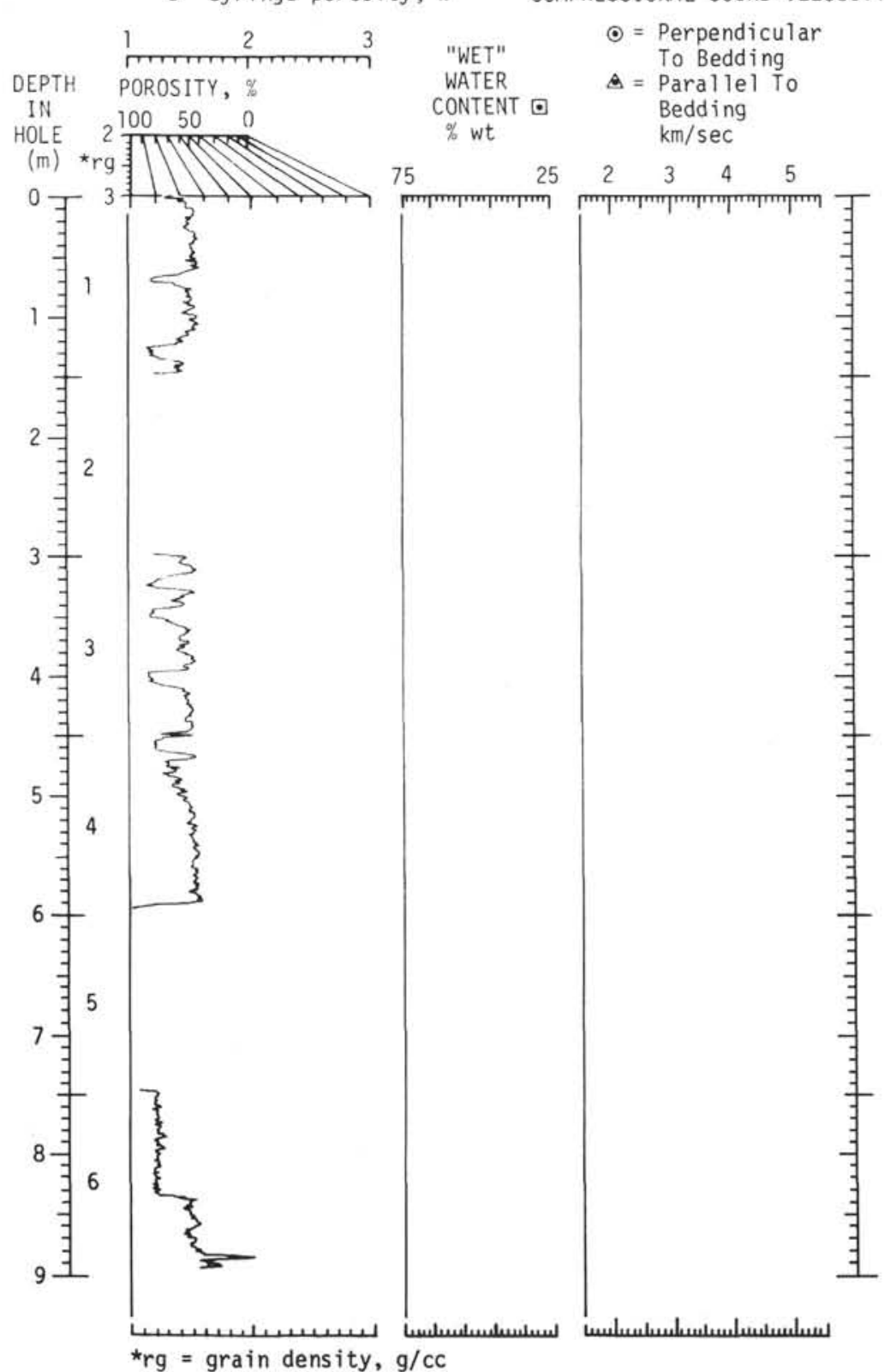

- = GRAPE WET-BULK DENSITY, g/cC

- Syringe porosity, \% COMPRESSIONAL SOUND VELOCITY
$\odot=$ Perpendicular
To Bedding
= Parallel To

$\begin{array}{cccc}\text { IN } & 10050 \quad 0 & \text { CONTENT } \square & \text { Bedding } \\ \text { HOLE } 20 & \mathrm{wt} & \mathrm{km} / \mathrm{sec}\end{array}$

(m) *rg 害 75

0 F 3 年

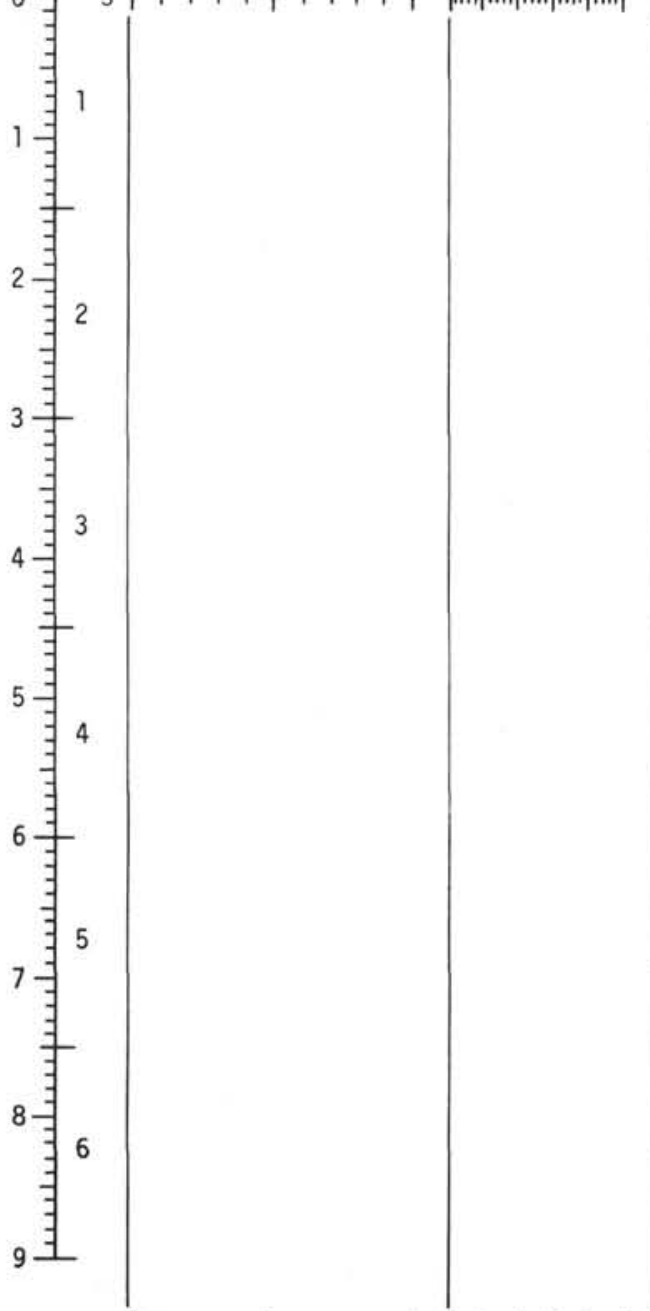

*rg = grain density, g/cc

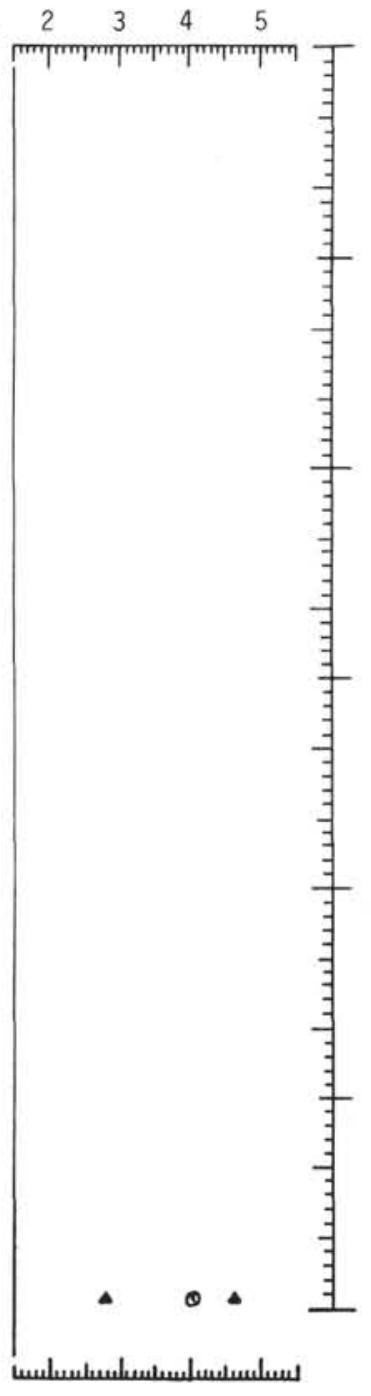


- $=$ GRAPE WET-BULK DENSITY, g/cC

○ Syringe porosity, \%

COMPRESSIONAL SOUND VELOCITY

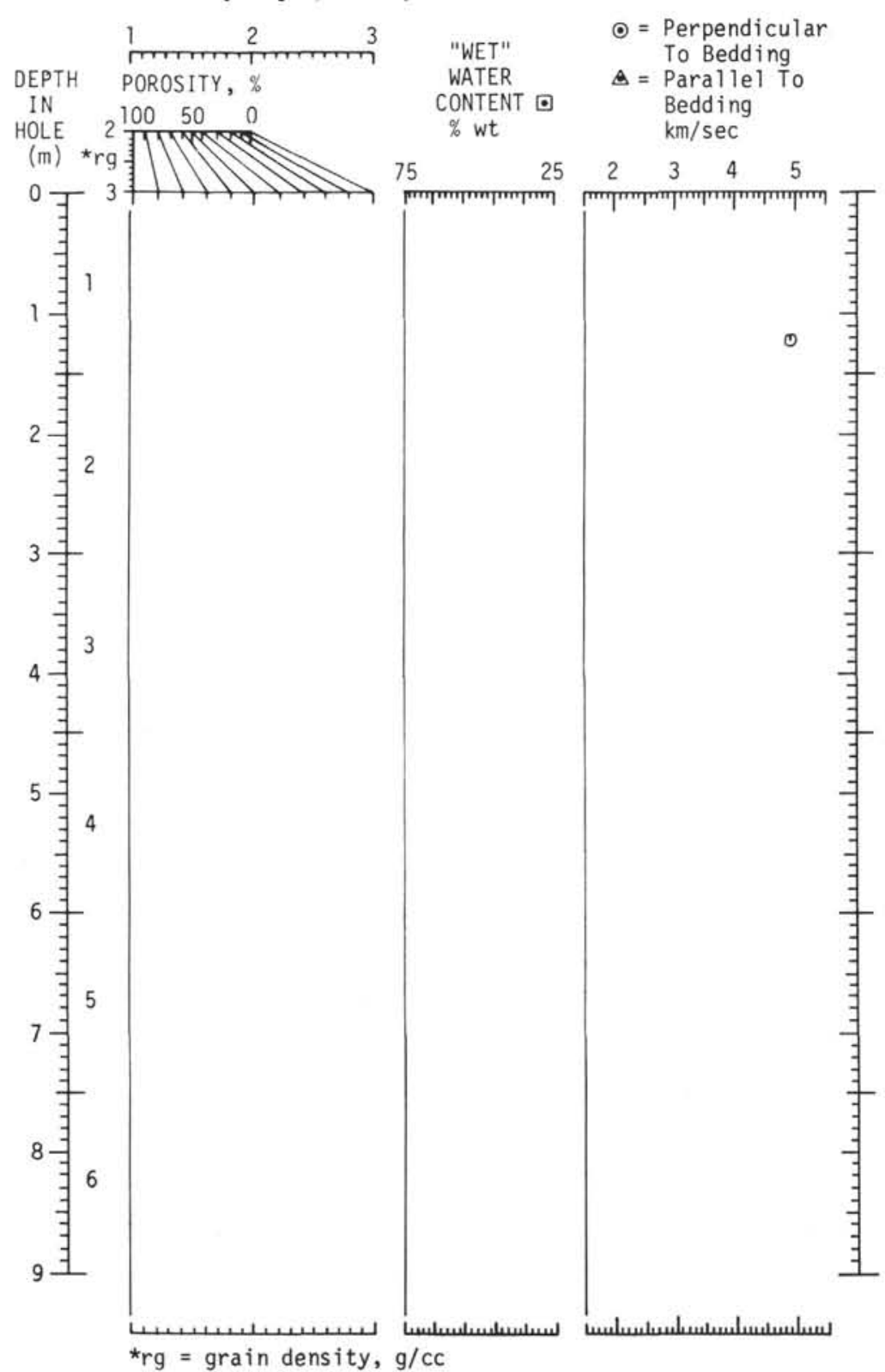

CORE 304-7

- $=$ GRAPE WET-BULK DENSITY, $\mathrm{g} / \mathrm{cc}$

- Syringe porosity, \% COMPRESSIONAL SOUND VELOCITY

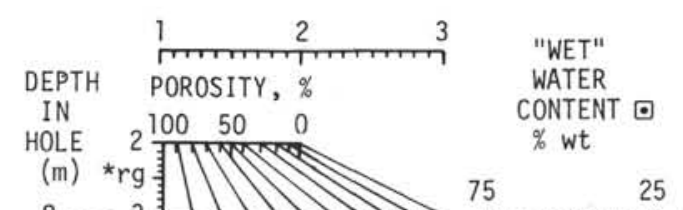

$\odot=$ Perpendicular To Bedding

$\Delta=$ Parallel To

Bedding

$\mathrm{km} / \mathrm{sec}$

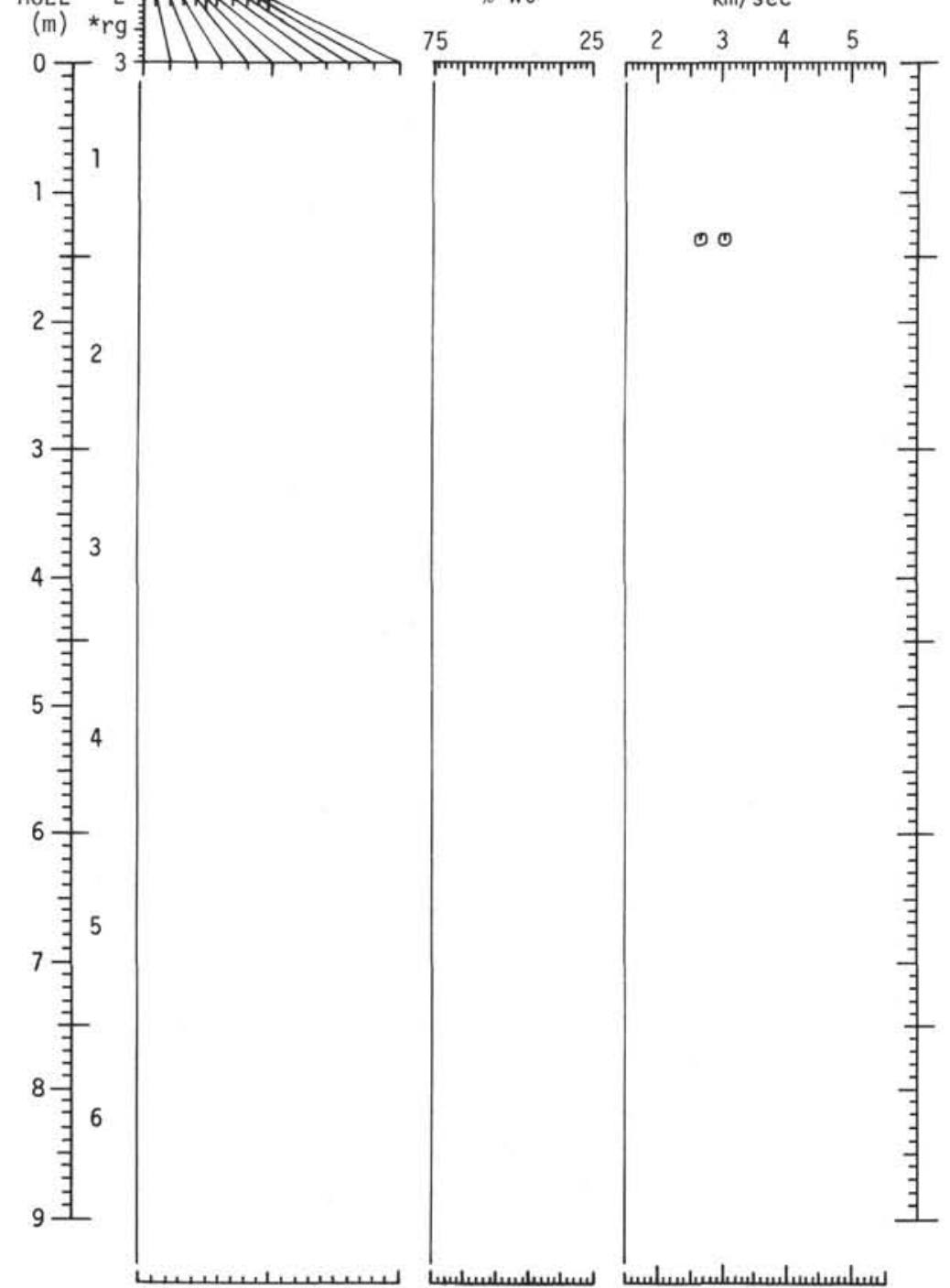

${ }^{*}$ rg = grain density, g/cc 
- Syringe porosity, \% COMPRESSIONAL SOUND VELOCITY

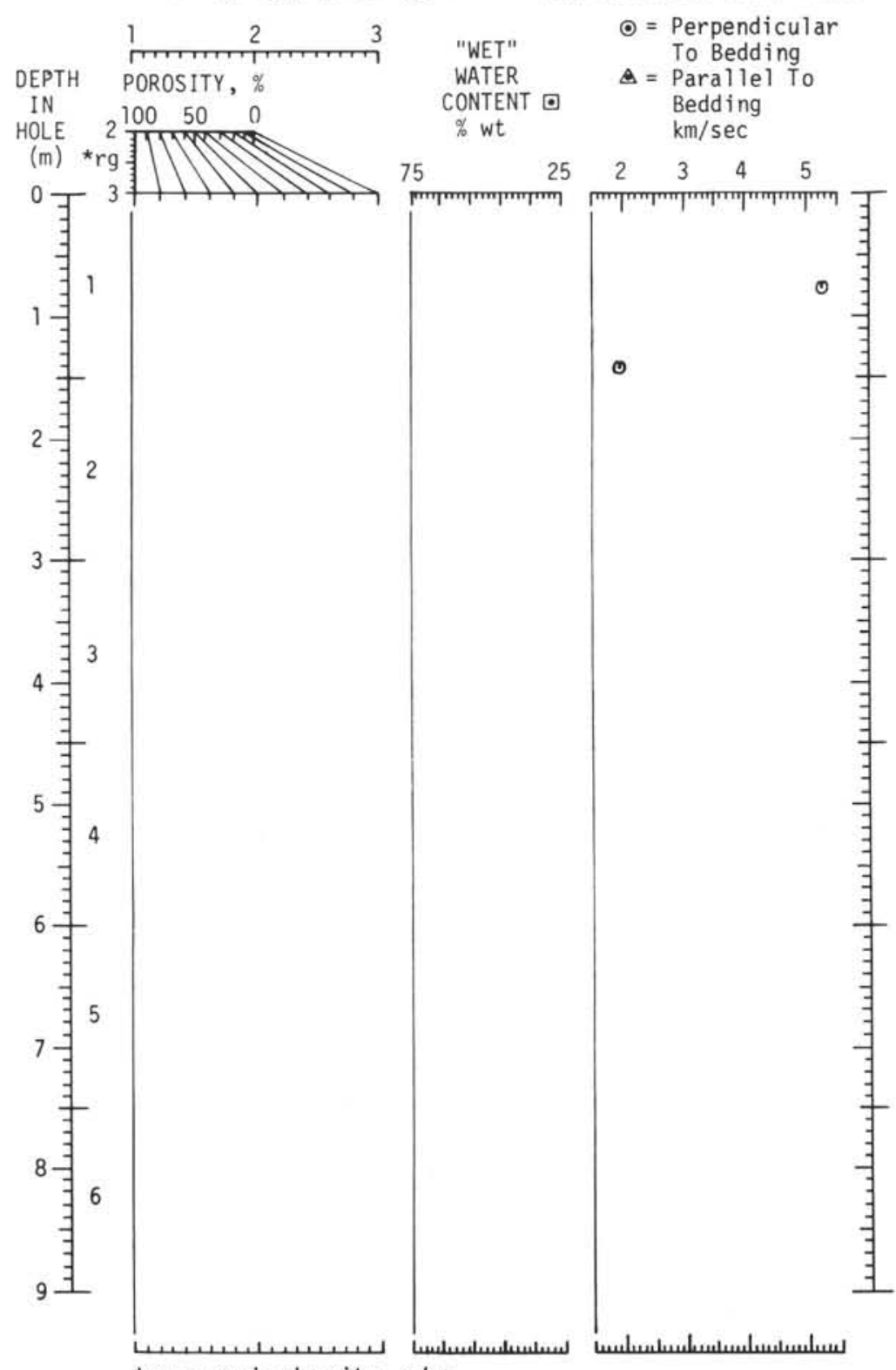

○ Syringe porosity, \% COMPRESSIONAL SOUND VELOCITY

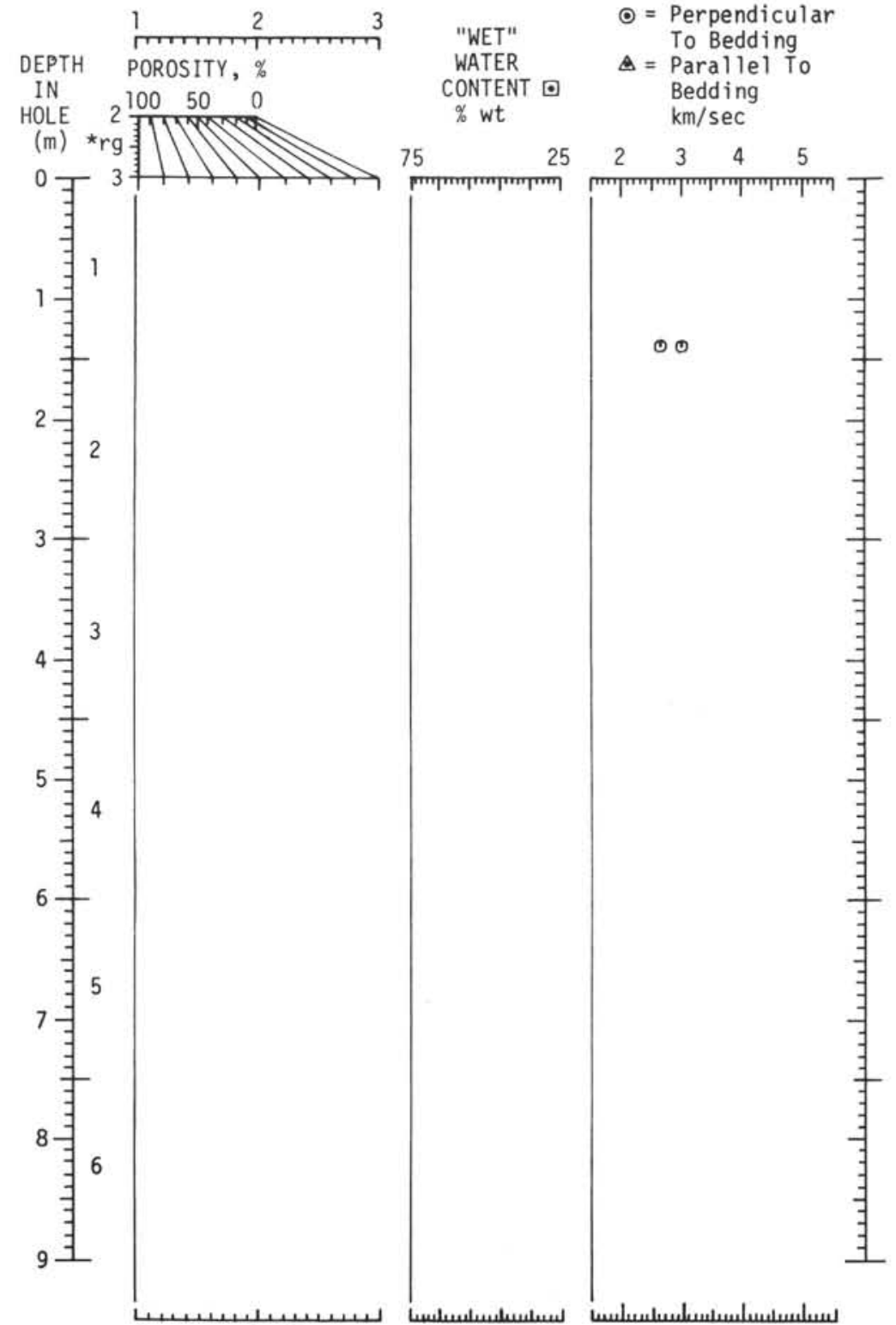

$*_{\text {rg }}=$ grain density, $g / c c$ 
CORE 304-10

- $=$ GRAPE WET - BULK DENSITY, g/CC

- Syringe porosity, \% COMPRESSIONAL SOUND VELOCITY

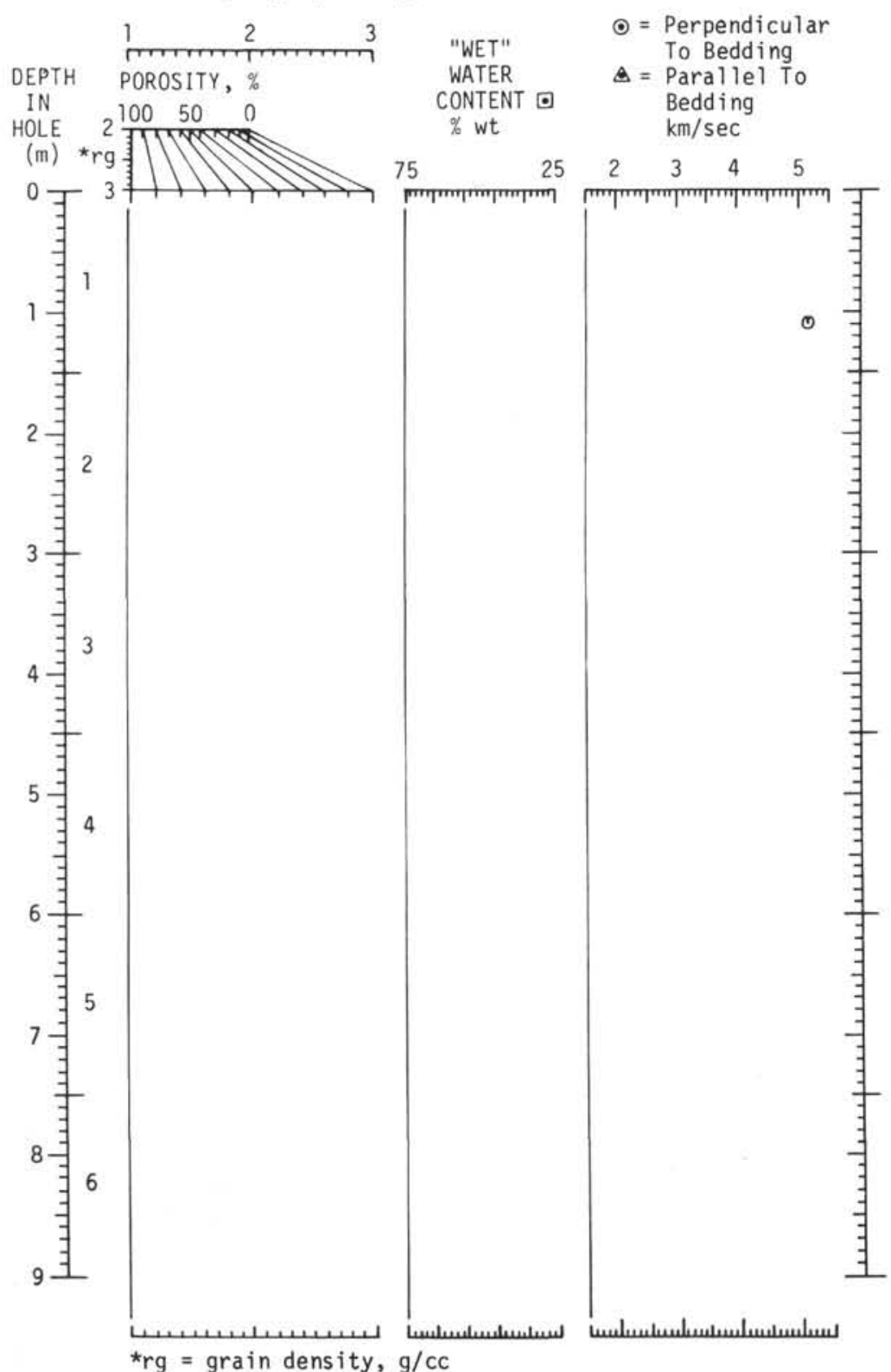

CORE 304-11

- = GRAPE WET-BULK DENSITY, g/cC

- Syringe porosity, $\%$ COMPRESSIONAL SOUND VELOCITY
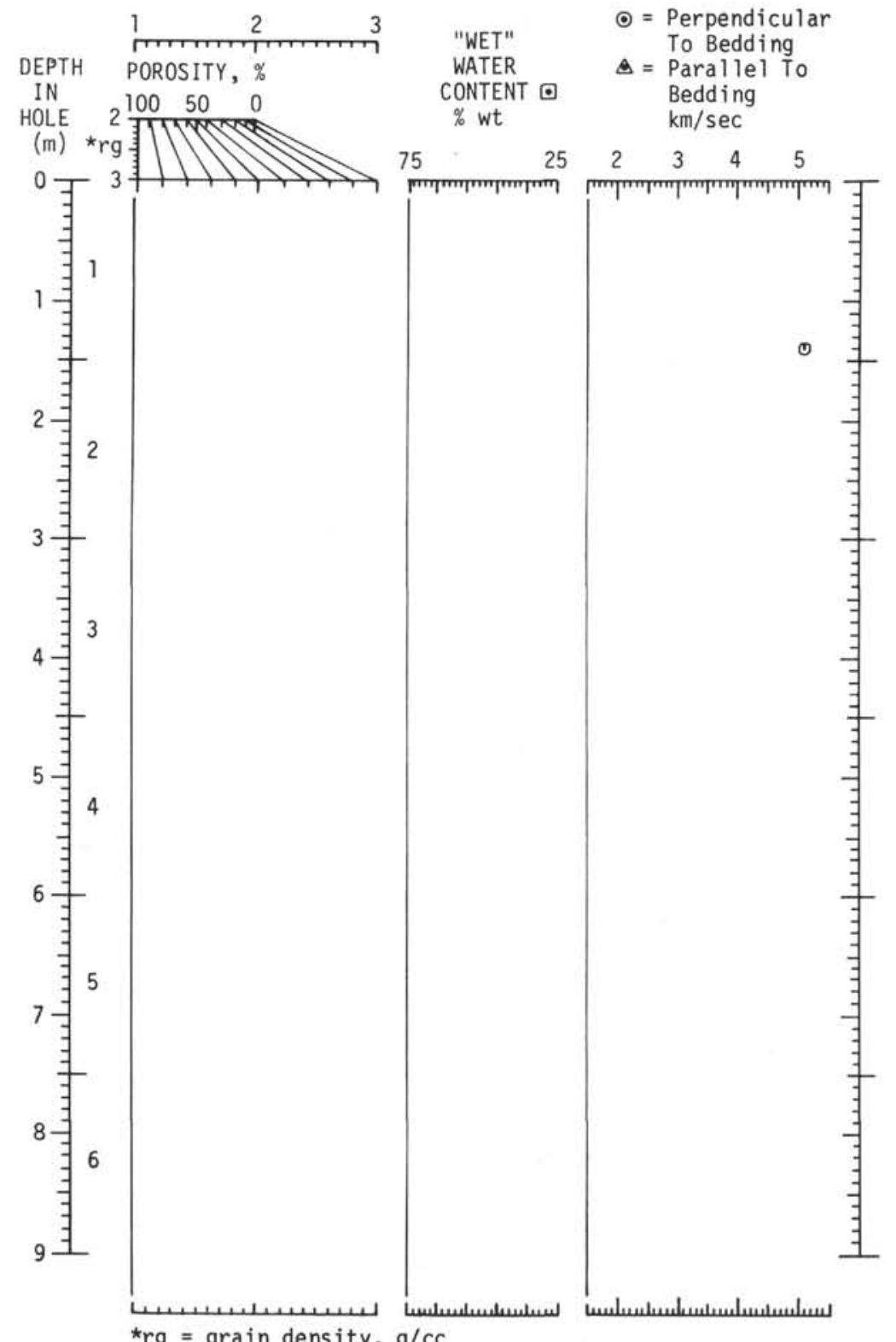
- $=$ GRAPE WET-BULK DENSITY, g/cC

- Syringe porosity, \% COMPRESSIONAL SOUND VELOCITY

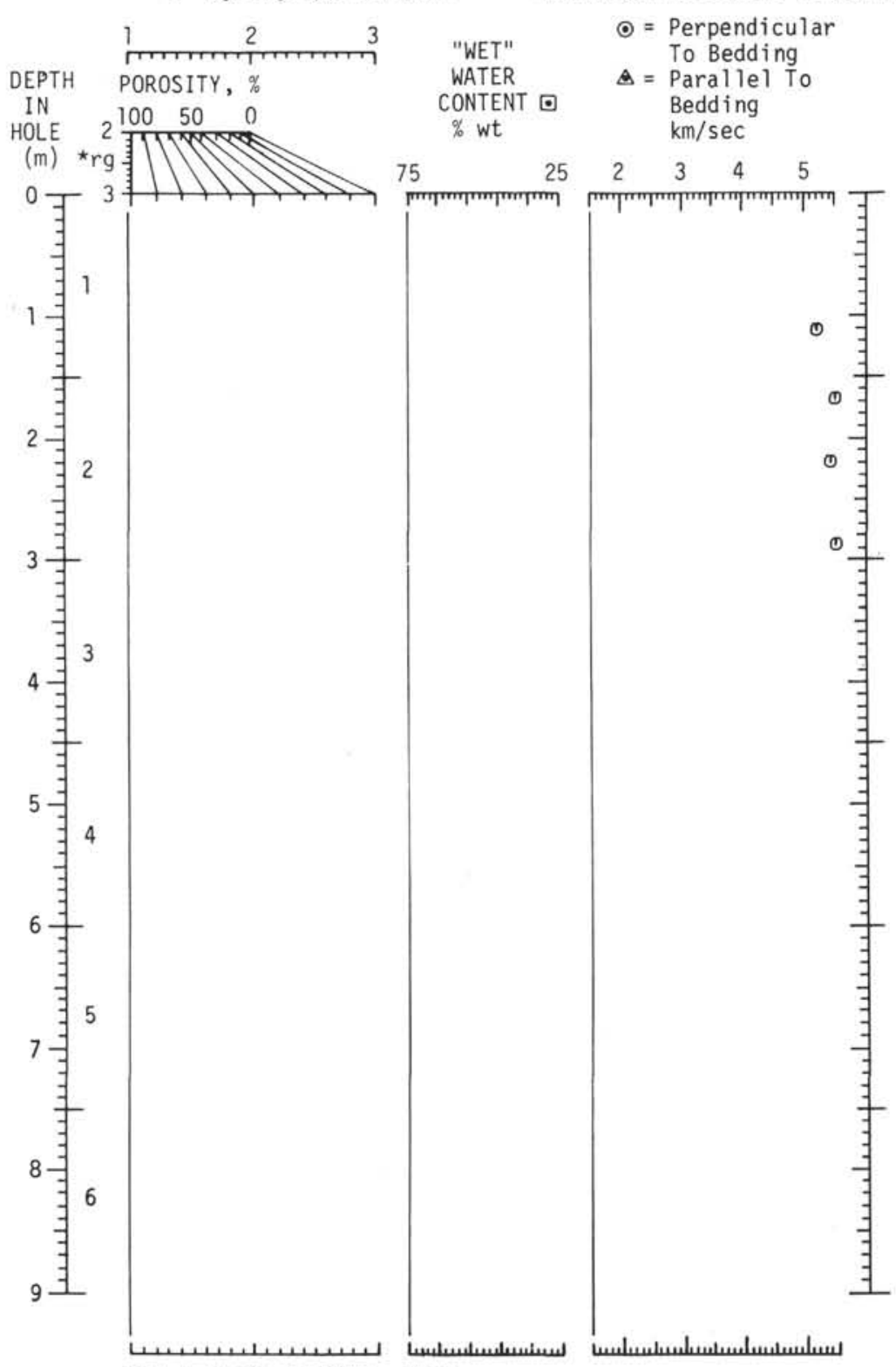

- = GRAPE WET-BULK DENSITY, g/cC

- Syringe porosity, \% COMPRESSIONAL SOUND VELOCITY

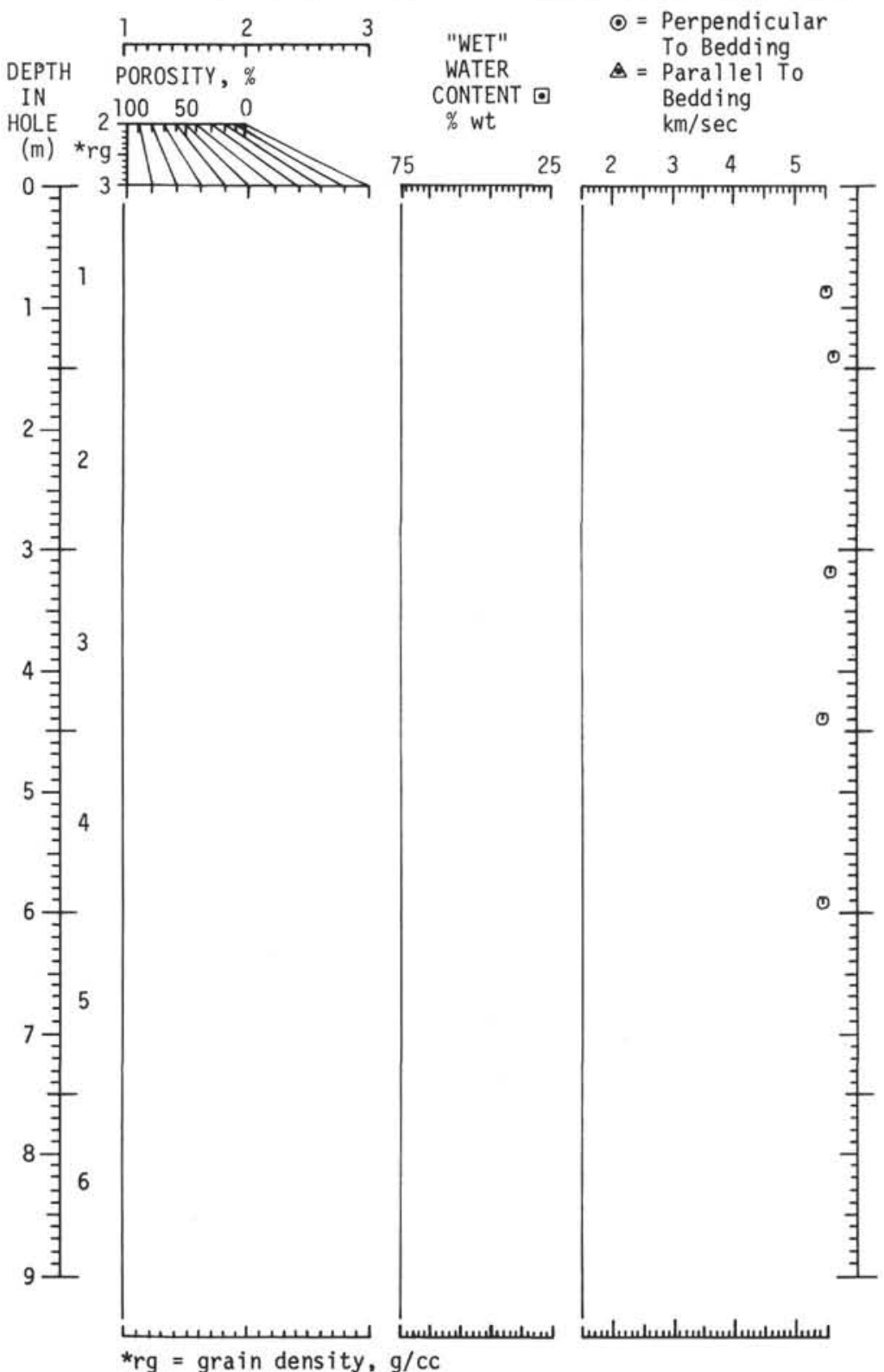




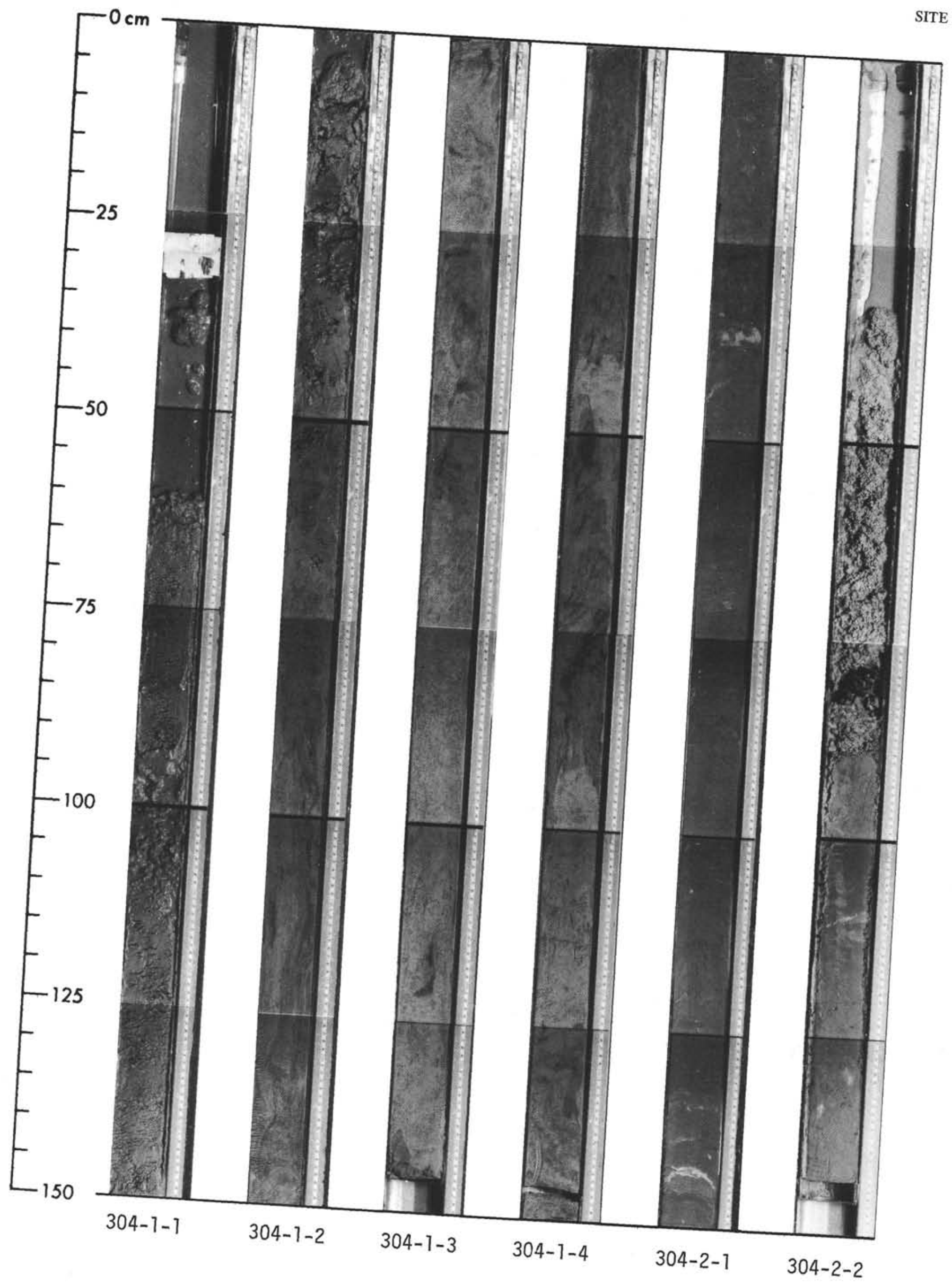




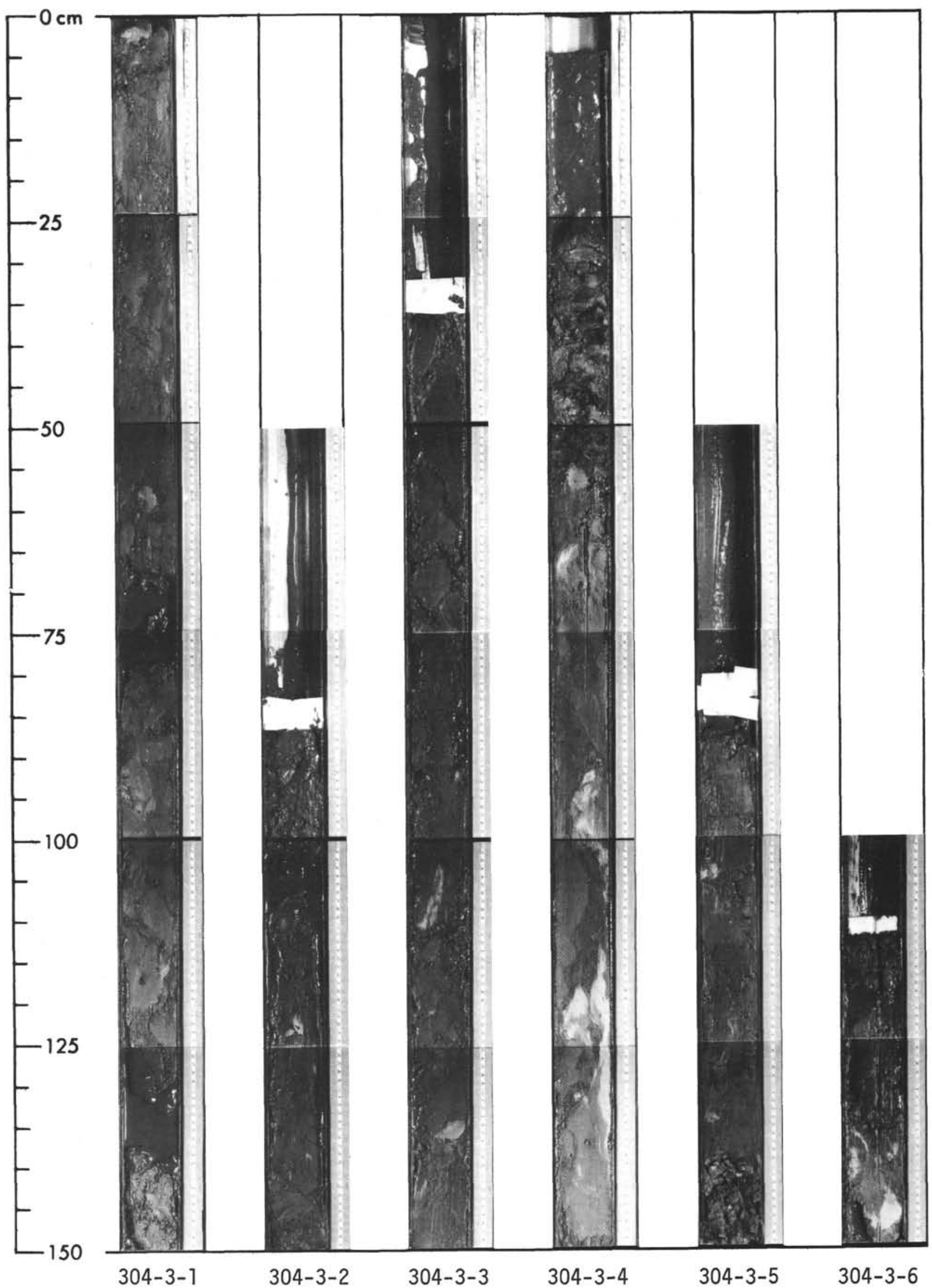




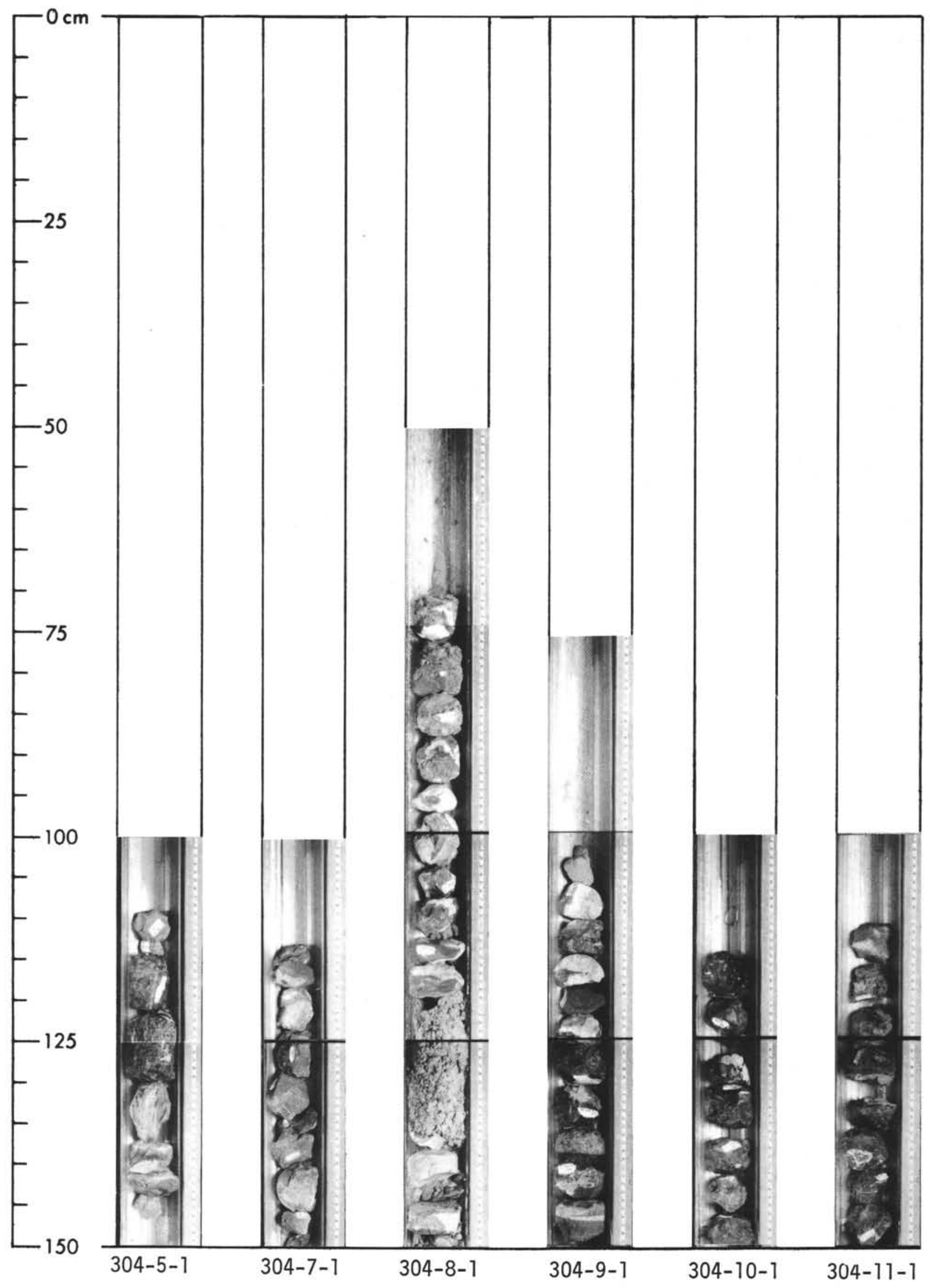




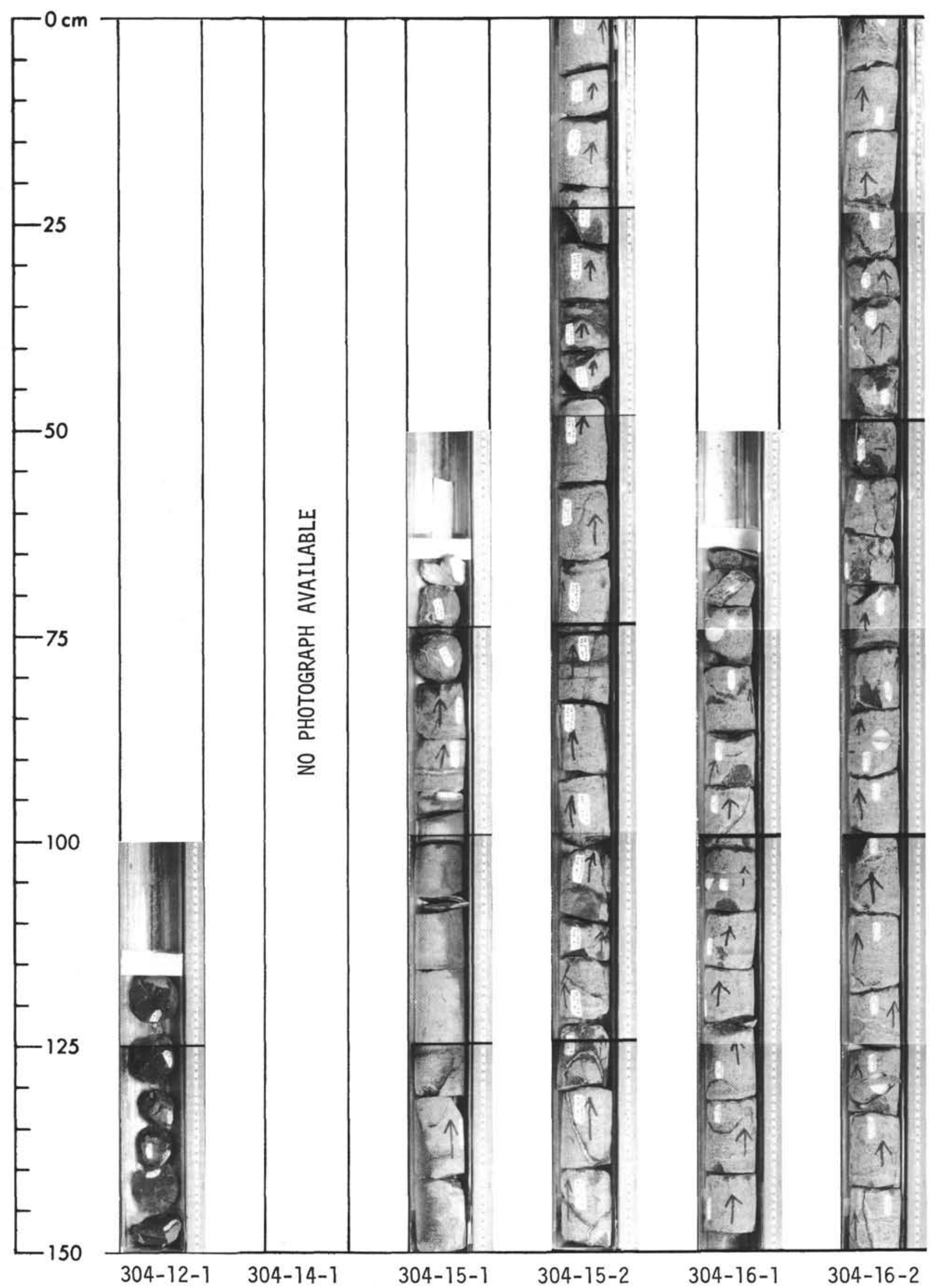




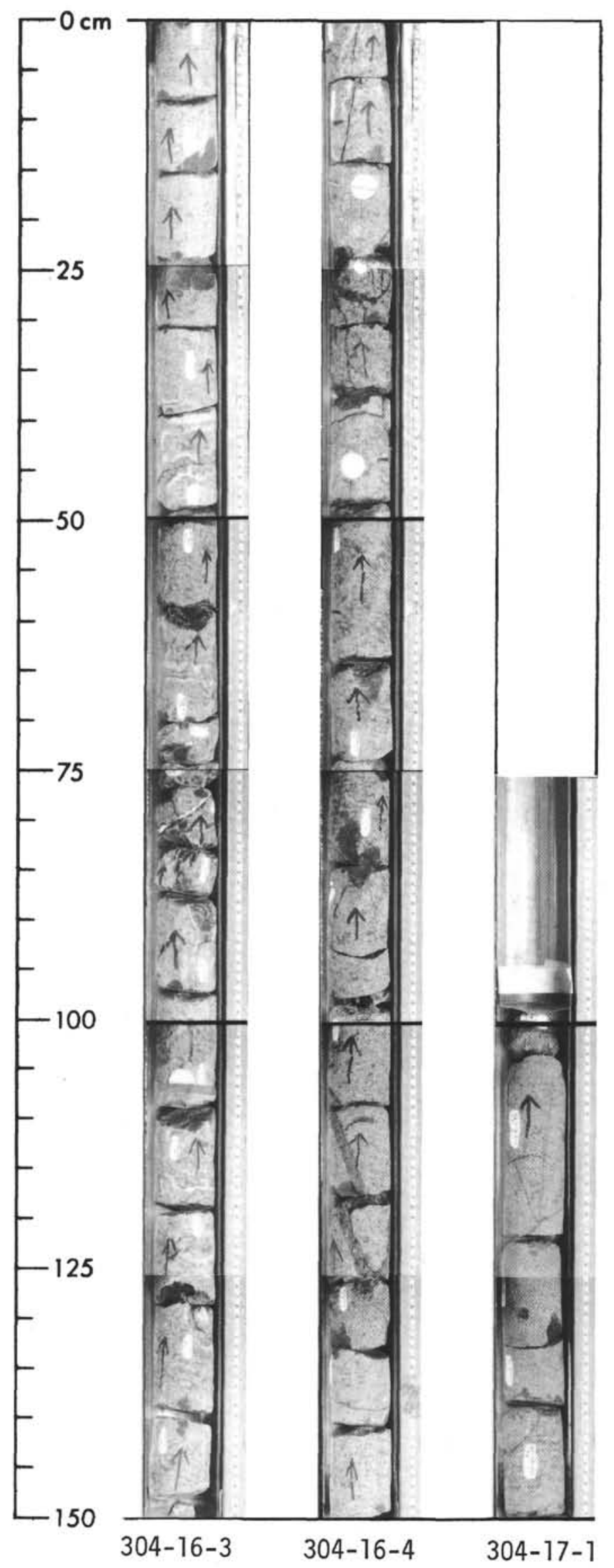

